\title{
Influence of convective transport on tropospheric ozone and its precursors in a chemistry-climate model
}

\author{
R. M. Doherty ${ }^{1}$, D. S. Stevenson ${ }^{1}$, W. J. Collins ${ }^{2}$, and M. G. Sanderson ${ }^{2}$ \\ ${ }^{1}$ Institute of Atmospheric and Environmental Science, University of Edinburgh, Edinburgh, UK \\ ${ }^{2}$ Hadley Centre for Climate Prediction and Research, Met Office, Exeter, UK
}

Received: 1 April 2005 - Published in Atmos. Chem. Phys. Discuss.: 7 June 2005

Revised: 29 September 2005 - Accepted: 10 November 2005 - Published: 5 December 2005

\begin{abstract}
The impact of convection on tropospheric $\mathrm{O}_{3}$ and its precursors has been examined in a coupled chemistryclimate model. There are two ways that convection affects $\mathrm{O}_{3}$. First, convection affects $\mathrm{O}_{3}$ by vertical mixing of $\mathrm{O}_{3}$ itself. Convection lifts lower tropospheric air to regions where the $\mathrm{O}_{3}$ lifetime is longer, whilst mass-balance subsidence mixes $\mathrm{O}_{3}$-rich upper tropospheric (UT) air downwards to regions where the $\mathrm{O}_{3}$ lifetime is shorter. This tends to decrease $\mathrm{UT}_{3}$ and the overall tropospheric column of $\mathrm{O}_{3}$. Secondly, convection affects $\mathrm{O}_{3}$ by vertical mixing of $\mathrm{O}_{3}$ precursors. This affects $\mathrm{O}_{3}$ chemical production and destruction. Convection transports isoprene and its degradation products to the UT where they interact with lightning $\mathrm{NO}_{\mathrm{x}}$ to produce PAN, at the expense of $\mathrm{NO}_{\mathrm{x}}$. In our model, we find that convection reduces UT $\mathrm{NO}_{\mathrm{x}}$ through this mechanism; convective down-mixing also flattens our imposed profile of lightning emissions, further reducing UT $\mathrm{NO}_{\mathrm{x}}$. Over tropical land, which has large lightning $\mathrm{NO}_{\mathrm{x}}$ emissions in the UT, we find convective lofting of $\mathrm{NO}_{\mathrm{x}}$ from surface sources appears relatively unimportant. Despite UT $\mathrm{NO}_{\mathrm{x}}$ decreases, $\mathrm{UT} \mathrm{O}_{3}$ production increases as a result of $\mathrm{UT}_{\mathrm{HO}}$ increases driven by isoprene oxidation chemistry. However, $\mathrm{UT} \mathrm{O}_{3}$ tends to decrease, as the effect of convective overturning of $\mathrm{O}_{3}$ itself dominates over changes in $\mathrm{O}_{3}$ chemistry. Convective transport also reduces $\mathrm{UT}_{3}$ in the mid-latitudes resulting in a $13 \%$ decrease in the global tropospheric $\mathrm{O}_{3}$ burden. These results contrast with an earlier study that uses a model of similar chemical complexity. Differences in convection schemes as well as chemistry schemes - in particular isoprene-driven changes are the most likely causes of such discrepancies. Further modelling studies are needed to constrain this uncertainty range.
\end{abstract}

Correspondence to: R. M. Doherty

(ruth@met.ed.ac.uk)

\section{Introduction}

The parameterisation of sub-grid scale convection is known to be a major uncertainty in both chemistry transport models (CTMs) and general circulation models (GCMs). A substantial element of divergence amongst CTM simulations arises from differences in convection parameterisation schemes, which have a particularly large influence on the distributions of short-lived species such as $\mathrm{NO}_{\mathrm{x}}\left(\mathrm{NO}+\mathrm{NO}_{2}\right)$, $\mathrm{HO}_{\mathrm{x}}\left(\mathrm{OH}+\mathrm{HO}_{2}\right)$, and ozone $\left(\mathrm{O}_{3}\right)$ (Prather and Jacob, 1997; Collins et al., 1999; Prather et al., 2001; Gauss et al., 2003; Lawrence and Rasch, 2005). Future emissions projections (e.g., Nakicenovic et al., 2000) indicate strong growth of $\mathrm{O}_{3}$ precursor emissions in the tropics - how these are processed by convection will be an important determinant of future $\mathrm{O}_{3}$ concentrations and the oxidising capacity of the atmosphere. GCM simulations project future regional changes in the distribution of convection over many parts of the globe (Cubasch et al., 2001). On interannual timescales shifts in convection associated with the El Niño Southern Oscillation modulate tropical tropsopheric chemistry variability (Ziemke and Chandra, 2003). Convection is therefore important in the context of understanding how climate variability and future climate change may affect tropospheric chemistry, via changes in both vertical mixing and the distribution of lightning $\mathrm{NO}_{\mathrm{x}}$ (e.g., Stevenson et al., 2005a).

Since $\mathrm{O}_{3}$, its lifetime and its production efficiency per $\mathrm{NO}_{\mathrm{x}}$ molecule all typically increase with height, deep convection strongly affects $\mathrm{O}_{3}$ and its precursors throughout the tropical tropospheric column (TTC), as shown in numerous measurement and modelling studies (e.g. Dickerson et al., 1987; Pickering et al., 1990, 1995). Considering $\mathrm{O}_{3}$ in isolation, increased vertical mixing tends to lower $\mathrm{TTC} \mathrm{O}_{3}$, as $\mathrm{O}_{3}$-poor air mixes upwards, to regions where its lifetime is longer, whilst $\mathrm{O}_{3}$-rich air mixes downwards through massbalance subsidence, to regions where its lifetime is shorter (e.g., Lelieveld and Crutzen, 1994; Lawrence et al., 2003).

(C) 2005 Author(s). This work is licensed under a Creative Commons License. 
However, the effects of convection on $\mathrm{O}_{3}$ precursors also need to be considered. Where there are surface $\mathrm{O}_{3}$ precursor sources, especially short-lived ones such as $\mathrm{NO}_{\mathrm{x}}$, isoprene $\left(\mathrm{C}_{5} \mathrm{H}_{8}\right)$ and other natural or anthropogenic hydrocarbons, convection significantly increases these precursor concentrations in the mid- and upper-troposphere (MT and UT) at the expense of lower troposphere (LT). Collins et al. (1999) and von Kuhlmann et al. (2004) identify convective uplifting of isoprene and its degradation products as a major source of tropical UT $\mathrm{HO}_{\mathrm{x}}$. Lawrence et al. (2003) find that lofting of surface $\mathrm{NO}_{\mathrm{x}}$ is a significant driver of increases in $\mathrm{O}_{3}$ production over much of the tropospheric column. Lightning in the tropics is a major $\mathrm{NO}_{\mathrm{x}}$ source directly associated with convection, with most $\mathrm{NO}_{\mathrm{x}}$ added to the UT (Pickering et al., 1998). There are also potential interactions between isoprene and lightning emissions (e.g., von Kuhlmann et al., 2004). An important isoprene degradation product is the peroxy acetyl radical $\left(\mathrm{CH}_{3} \mathrm{COO}_{2}\right)$, which can affect $\mathrm{NO}_{\mathrm{x}}$ by promoting PAN formation over land areas where isoprene and lightning $\mathrm{NO}_{\mathrm{x}}$ emissions are co-located. The net impact of convective mixing is thus sensitive to the profile of $\mathrm{O}_{3}$ and its precursors prior to convection, and is a complex balance between transport and a variety of chemical effects. Lawrence et al. (2003) found the effect of convective changes in precursor emissions on the tropospheric $\mathrm{O}_{3}$ burden to be more important than the convective redistribution of $\mathrm{O}_{3}$.

In this paper, the role of convective mixing in determining the distribution of $\mathrm{O}_{3}$ and its precursors is investigated using the STOCHEM-HadAM3 coupled chemistry-climate model. Section 2 describes the model and the experiments. Section 3 describes the distribution of convection and evaluates model results with observations. Then the influence of convection on $\mathrm{O}_{3}$, its precursors and on $\mathrm{O}_{3}$ production and destruction is discussed for tropical land and ocean. Changes to the global $\mathrm{O}_{3}$ budget related to convection are then outlined. Section 4 discusses the results of this paper compared to those from other studies, highlights model differences and uncertainties; Sect. 5 presents conclusions.

\section{Model and experiments}

The current version of STOCHEM-HadAM3 coupled CTMGCM model has been described in detail in previous studies (Sanderson et al., 2003a, b; Stevenson et al., 2004), so we present a limited description of relevant model processes here. HadAM3 (Pope et al., 2000) is the atmospheric component of the HadCM3 atmosphere-ocean general circulation model (GCM). HadAM3 was driven by prescribed monthly sea-surface temperatures (SSTs) for 1980-2002 and was run at standard resolution of $3.75^{\circ}$ longitude by $2.5^{\circ}$ latitude and 19 vertical levels. These levels are concentrated at the surface and extend to $10 \mathrm{hPa}$. Meteorological fields are passed to the CTM every $3 \mathrm{~h}$.
STOCHEM is a Lagrangian tropospheric CTM, first described by Collins et al. (1997), with subsequent major updates to the chemistry (Collins et al., 1999), convection (Collins et al., 2002) and deposition schemes (Sanderson et al., 2003a). Its atmosphere is divided into 50000 equal mass air parcels that are advected by HadAM3 winds. Air parcels are mapped onto a $5^{\circ}$ longitude by $5^{\circ}$ latitude horizontal grid with 9 equally spaced vertical levels, which extends from the surface to $\sim 100 \mathrm{hPa}$. Stratospheric $\mathrm{O}_{3}$ influx, calculated from a present-day stratospheric $\mathrm{O}_{3}$ climatology ( $\mathrm{Li}$ and Shine, 1995), is distributed into the troposphere by HadAM3 vertical winds at $100 \mathrm{hPa}$ as a flux term. This means that the stratospheric influx should not be affected by convective mixing, since neither the $100 \mathrm{hPa}$ winds or $\mathrm{O}_{3}$ climatology are changed; the small change in inferred $\mathrm{O}_{3}$ stratospheric influx (calculated as a residual term) in Table 1 (Sect. 3.4) reflects random differences in air parcel sampling of the atmosphere between model simulations. Stratospheric input of $\mathrm{HNO}_{3}$ is modelled similarly assuming a fixed $\mathrm{N}: \mathrm{O}_{3}$ ratio of 1:1000 (Murphy and Fahey, 1994). In this study, the chemical fields from STOCHEM are not fed back into the radiation scheme in HadAM3.

The convection scheme in HadAM3 is a bulk mass-flux scheme with an instability closure (Gregory et al., 1997) and is based on that of Tiedtke (1989). STOCHEM uses the Collins et al. (2002) Lagrangian convective mixing scheme. This mixing scheme uses the 3-D convective updraught mass fluxes generated from HadAM3 and represents rapid convective updraughts, entrainment and detrainment of air parcels, and slower mass balance subsidence of larger regions of surrounding air. Although downdraughts are calculated in the GCM convection scheme, these are not implemented in the mixing scheme. Collins et al. (2002) compare simulated radon $\left({ }^{222} \mathrm{Rn}\right)$ profiles against available measurements. These were summertime mid-latitude continental and coastal sites. The Lagrangian mixing scheme compares favourably with observations in the continental regions. In coastal regions, the model underestimates radon in the boundary layer but elsewhere shows good agreement. Tropical surface simulations of ${ }^{222} \mathrm{Rn}$ were also evaluated, and similar results to those of earlier modelling studies were found - with ${ }^{222} \mathrm{Rn}$ underestimates in spring at Mauna Loa, and ${ }^{222} \mathrm{Rn}$ overestimates/underestimates in spring/summer at Bermuda. Further details can be found in Collins et al. (2002).

Generation of lightning $\mathrm{NO}_{\mathrm{x}}$ is linked to the convection scheme following Price et al. (1997). Convective precipitation from HadAM3 is used to identify lightning occurrence, and cloud height and thickness used to calculate the number of flashes for marine and continental clouds. The global production of lightning NO is scaled to be roughly $7 \mathrm{Tg} \mathrm{N} / \mathrm{yr}$ and global isoprene emissions are $\sim 575 \mathrm{Tg} \mathrm{yr}^{-1}$. The profiles of Pickering et al. (1998) are used to vertically distribute the lightning $\mathrm{NO}_{\mathrm{x}}$ emissions for three regimes: midlatitude continental, tropical continental and tropical marine; mid-latitude marine regions are treated like tropical 
marine regions. For these three regimes most lightning $\mathrm{NO}_{\mathrm{x}}$ (55-75\% depending on regime) is emitted in the UT above $8 \mathrm{~km}$. The modelled global annual-average lightning $\mathrm{NO}_{\mathrm{x}}$ spatial distribution is in fairly good agreement with the lightning flash rate recently derived from satellite by Christian et al. (2003). Note that only a qualitative comparison is possible since NO emissions are not directly proportional to the total number of flashes, as the cloud-to-ground and intercloud flashes produce different amounts of $\mathrm{NO}_{\mathrm{x}}$. However, the global annual land to ocean ratio of lightning $\mathrm{NO}_{\mathrm{x}}$ emissions in our model is $\sim 30: 1$, whilst the land/ocean lightning flash rate derived by Christian et al. (2003) is 10:1. Since modelled and observed precipitation climatologies have high spatial agreement (not shown), this suggests that oceanic lightning $\mathrm{NO}_{\mathrm{x}}$ is underestimated by the Price et al. (1997) scheme. This was also found by Labrador et al. (2005). In our model set-up we use the Pickering et al. (1998) vertical profiles to distribute lightning $\mathrm{NO}_{\mathrm{x}}$ emissions in all simulations (even when convective mixing is switched off). Consequently, in the control experiment these distributed emissions are then also subject to convective mixing once they enter the model transport and mixing schemes.

Two experiments were performed for the period 1980 2000: a "control" experiment with normal convective mixing of $\mathrm{O}_{3}$ and its precursors, and a "convection off" experiment with no convective mixing of $\mathrm{O}_{3}$ or its precursors, although convection in the climate model and lightning $\mathrm{NO}_{\mathrm{x}}$ emissions (see above) still occur. Water vapour concentrations also do not change between the two experiments.

Anthropogenic and natural emissions of global trace gases in both experiments are identical. Anthropogenic emissions come from the SRES A2 scenario (Nakićenović et al., 2000) for the present-day period. Note that emissions from all the different SRES scenarios are similar over this period. Natural emissions are as given in Stevenson et al. (2004). For analysis, two different tropopause definitions were used: (i) a chemical tropopause defined using the $150 \mathrm{ppbv} \mathrm{O}_{3}$ isopleth (the definition used by Prather et al. (2001); and (ii) a physical tropopause based on the WMO definition and diagnosed in HadAM3. In both cases the same tropopause mask was used for the analysis of the control and convection off simulations. For the chemical tropopause this involved masking any grid boxes where monthly-mean $\mathrm{O}_{3}$ mixing ratios exceeded $150 \mathrm{ppbv}$ in either of the two simulations.

\section{Results}

Figure 1a depicts annual-average convective updraught mass fluxes from HadAM3 for 1991-1996 (to be coincident with the ERA-40 renalayses period, see below). Deep convection in the inter-tropical convergence zone (ITCZ) and South Pacific Convergence Zone is clearly delineated (Figs. 1a, b). Substantial convection at $\sim 200 \mathrm{hPa}$ (eta=0.2) can also be seen over SE Asia, southern N America, and E Siberia/Japan
(Fig. 1a). Convection that extends up to the MT is also depicted in the tropics and in mid-latitudes, particularly over the southern oceans and northern continents, and is typically associated with frontal activity (Fig. 1b). The anomalies over the Himalayas are non-precipitating convection and appear to be a consequence of model orography. Convective updraught mass fluxes from ERA-40 reanalyses ("on-line" fluxes - see Sect. 4; Olivié et al., 2004) are displayed in Figs. 1d-f. Compared to ERA-40, HadAM3 has higher mass fluxes (by up to a factor of 2) and convection also generally reaches greater altitudes (Figs. 1c, f). It should be stressed that the distribution and strength of convection are poorly constrained by observations, and it is not obvious that ERA-40 values reflect the real atmosphere, although they perhaps represent our best current estimate.

\subsection{Evaluation of modelled $\mathrm{NO}_{\mathrm{x}}, \mathrm{PAN}$ and $\mathrm{O}_{3}$ against ob- servations}

Several aircraft campaigns have measured atmospheric composition, and these provide useful data to evaluate model simulations. Emmons et al. (2000) produced data composites for several species, including $\mathrm{NO}_{\mathrm{x}}, \mathrm{PAN}$ and $\mathrm{O}_{3}-$ these have been updated to incorporate subsequent campaigns, and the data have been binned onto a $5^{\circ} \times 5^{\circ} \times 1 \mathrm{~km}$ grid (see http://gctm.acd.ucar.edu/data). Figure 2 plots annual mean profiles for the tropics over land and ocean. Each point in the vertical profile represents the mean of several grid boxes - in turn these represent the mean of several aircraft measurements. The numbers adjacent to the right-hand vertical axis indicate the number of grid boxes contributing to the mean. In addition, the standard deviation of the grid boxes is depicted by a box surrounding the mean value. It should be noted that these observed profiles sample only a small fraction of the atmosphere, both spatially and temporally. Also plotted in Fig. 2 are model results, sampled in the same way as the mean observations for the control (solid red line) and convection off simulations (solid green line). The \pm 1 standard deviation for the control simulation is also depicted (red dashed line). Annual-mean profiles for the midlatitudes can be seen at http://www.met.ed.ac.uk/ $\sim$ dstevens/ convection_paper/midlatseval.pdf.

Figures $2 \mathrm{a}$ and $\mathrm{d}$ are for $\mathrm{NO}_{\mathrm{x}}$, and show a "C"-shaped profile over land. Over tropical land, the model somewhat underestimates $\mathrm{NO}_{\mathrm{x}}$ in the LT, and overestimates $\mathrm{NO}_{\mathrm{x}}$ in the UT. This may be due to over-vigorous convection, or perhaps deficiencies in either the lightning $\mathrm{NO}_{\mathrm{x}}$ emission profiles and/or our application of these in STOCHEM as discussed in Sect. 2. In a parallel study, with perturbed lightning $\mathrm{NO}_{\mathrm{x}}$ emissions, we found that a reduction in global lightning NO production from 7 to $3.5 \mathrm{Tg} \mathrm{N} / \mathrm{yr}$ led to an underestimate of tropical UT $\mathrm{NO}_{\mathrm{x}}$, and a larger underestimate of

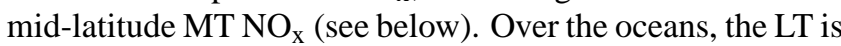
better represented, but here UT $\mathrm{NO}_{\mathrm{x}}$ is underestimated. This may reflect an underestimate of lightning over the oceans 


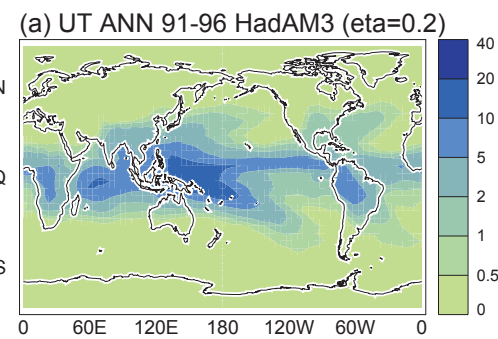

(d) UT ANN 91-96 ERA-40 (eta=0.2)

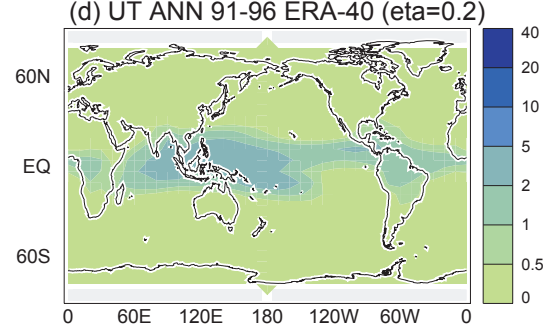

(g) UT ANN 95 MATCH-MPIC (eta=0.2)

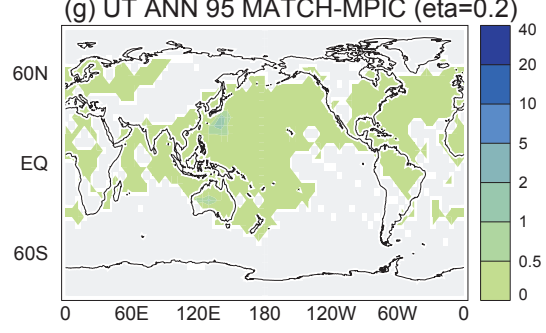

(b) MT ANN 91-96 HadAM3 (eta=0.6)

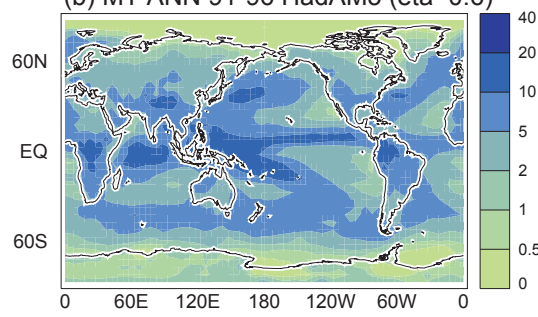

(e) MT ANN 91-96 ERA-40 (eta=0.6)

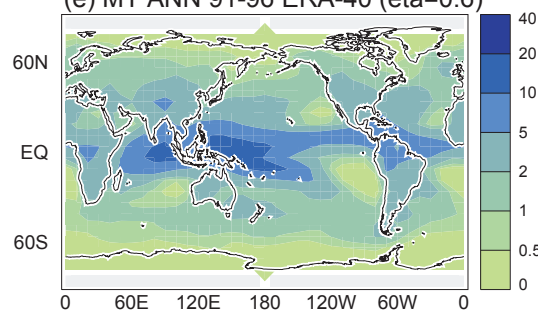

(h) MT ANN 95 MATCH-MPIC (eta $=0.6$ )

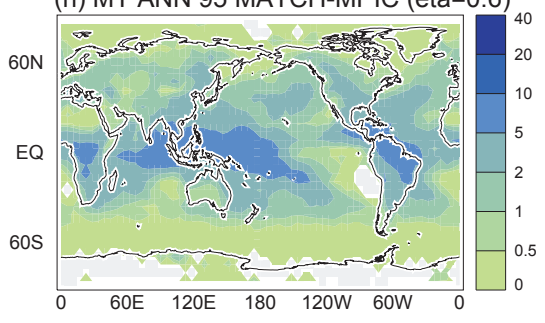

(c) ANN 91-96 HadAM3

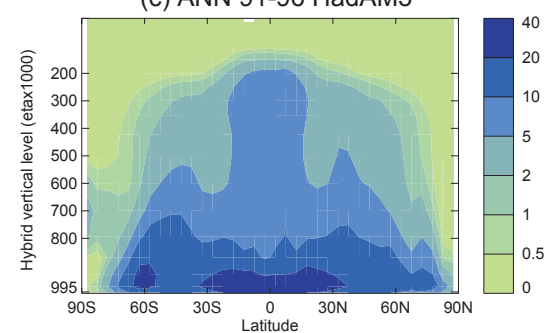

(f) ANN 91-96 ERA-40

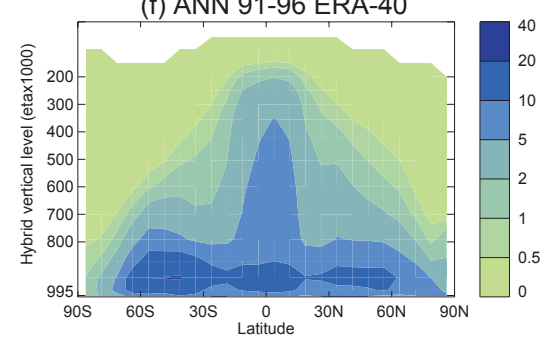

(i) ANN 95 MATCH-MPIC

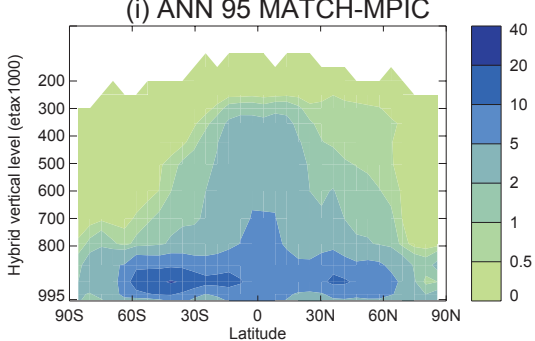

Fig. 1. Annual-average convective updraught mass fluxes $(\mathrm{g} / \mathrm{m} 2 / \mathrm{s})$ in the UT (eta=0.2, $\sim 200 \mathrm{hPa}$ ), MT (eta=0.6 600 hPa) and zonal-mean vs. altitude fluxes derived from HadAM3 (1991-1996) (a-c), ERA-40 reanalayses (1991-1996) (d-f) and MATCH-MPIC (1995) (g-i).

compared to the land. As discussed in Sect. 2, the model's interactive lightning scheme generates a land:ocean ratio in lightning $\mathrm{NO}_{\mathrm{x}}$ emissions that is rather more land-biased than recent satellite observations suggest. Nevertheless, model and observations are nearly always within a standard deviation of each other. The convection off profile (in green) clearly shows the strong enhancement in tropical UT $\mathrm{NO}_{\mathrm{x}}$ that occurs when convective mixing is switched off; this is partially due to the fact that the lightning $\mathrm{NO}_{\mathrm{x}}$ profile is still applied in the convection off case, and there is less downmixing of this major UT $\mathrm{NO}_{\mathrm{x}}$ source. In the mid-latitudes UT $\mathrm{NO}_{\mathrm{x}}$ is underestimated and $\mathrm{LT} \mathrm{NO}_{\mathrm{x}}$ overestimated, particularly over land (not shown). This could suggest too little convective mixing in mid-latitudes (although this would be surprising given that HadAM 3 convective updraught mass fluxes are stronger than those derived from ERA-40 reanalyses, as discussed in Sect. 3). Underestimates in UT $\mathrm{NO}_{\mathrm{x}}$ may also arise because of PAN over-production (see below) or under-estimation of mid-latitude lightning $\mathrm{NO}_{\mathrm{x}}$ sources.

Figures $2 \mathrm{~b}$ and e show PAN profiles, and again show generally good agreement, although with a slight tendency for the model to overestimate PAN, particularly in the UT. This tendency for the model to overestimate PAN is more evident in northern mid-latitudes (not shown), and may reflect overproduction of the peroxy acetyl radical from higher hydrocarbons. The convection off profile for the tropics clearly shows the major influence of convection on PAN in the model, almost doubling its MT and UT concentrations over land, due to the vertical lofting of relatively short-lived hydrocarbons and their degradation products (in particular isoprene-related species). In turn, convection-enhanced PAN formation contributes to the reductions in $\mathrm{UT} \mathrm{NO}_{\mathrm{x}}$ (Figs. 2a and d).

Finally, Figs. 2c and $\mathrm{f}$ show tropical $\mathrm{O}_{3}$ profiles. The model typically underestimates $\mathrm{O}_{3}$ throughout the profile, by around 5-10 ppbv over land and 10-15 ppbv over the ocean. A similar underestimate was also found for the same model (but with slightly different emissions) in the $\mathrm{O}_{3}$ evaluation against ozonesonde data performed in Stevenson et al. (2004) and Dentener et al. (2005). It seems likely that the $\mathrm{O}_{3}$ destruction chemistry is rather too active in the model - in a recent model inter-comparison (Stevenson et al., 2005b), the STOCHEM model coupled to HadAM3 had the shortest tropospheric $\mathrm{O}_{3}$ lifetime of all the models sampled. The ozone lifetime is mainly determined by the flux through the main $\mathrm{O}_{3}$ sink $\left(\mathrm{O}\left({ }^{1} \mathrm{D}\right)+\mathrm{H}_{2} \mathrm{O}\right)$. This reaction is also the main source of $\mathrm{OH}$. The model's methane lifetime (and hence tropical 

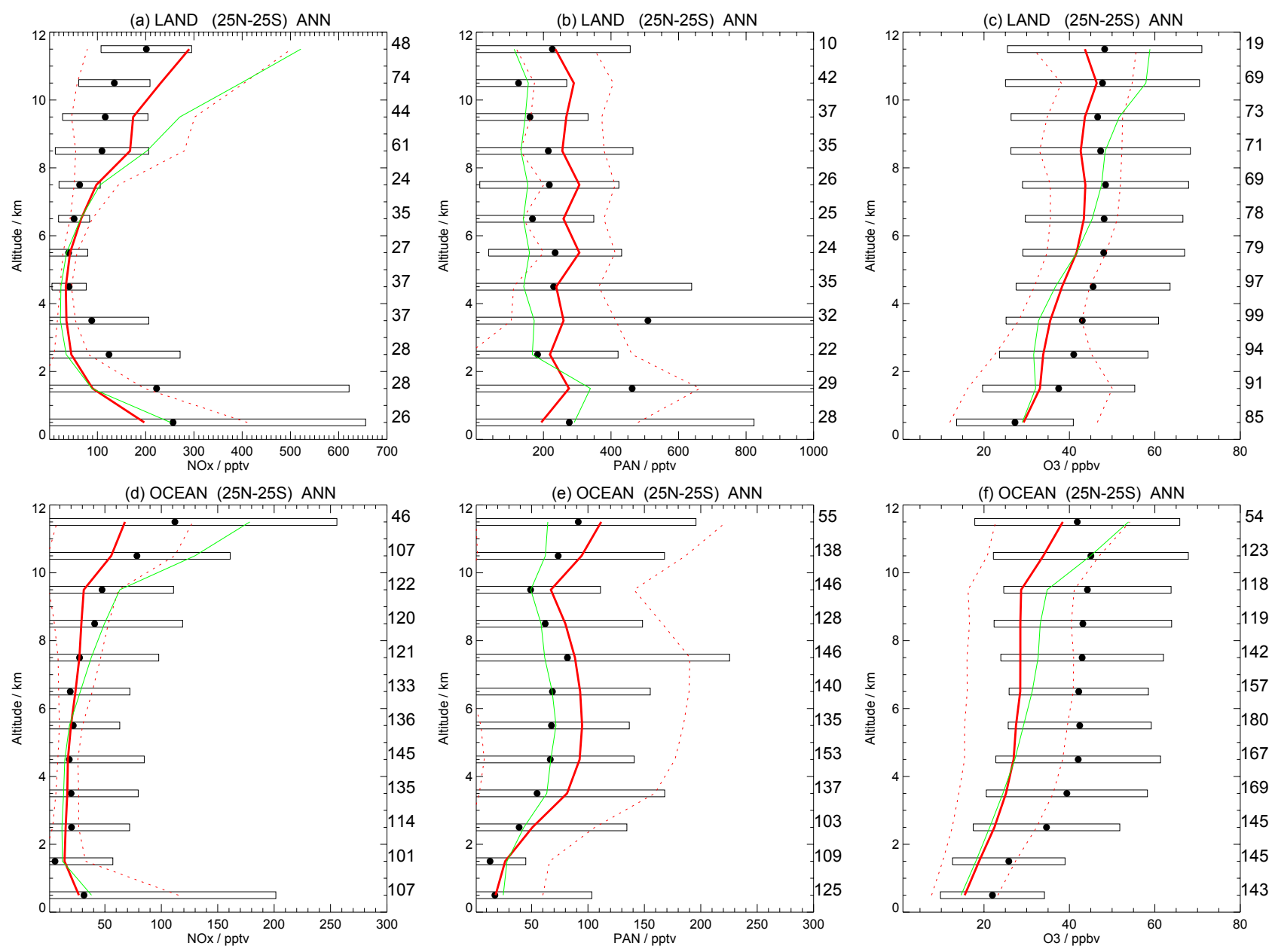

Fig. 2. $\mathrm{NO}_{\mathrm{x}}(\mathbf{a}, \mathbf{b}), \mathrm{PAN}(\mathbf{c}, \mathbf{d})$ and $\mathrm{O}_{3}(\mathbf{e}, \mathbf{f})$ simulated and observed profiles over tropical land and ocean. The points represent annual mean tropical $\left(25^{\circ} \mathrm{N}-25^{\circ} \mathrm{S}\right)$ profiles and are mean values of gridded aircraft measurements from the SASS database http://gctm.acd.ucar.edu/data (Emmons et al., 2000). The numbers adjacent to the right-hand vertical axis indicate the number of grid boxes contributing to the mean. The standard deviation is depicted by a box surrounding the mean value. The curves represent HadAM3-STOCHEM model mean values for the same spatial and temporal locations as the observations for the control (red) and convection off (green) simulations. The standard deviation for the control simulation is denoted by dashed lines.

$\mathrm{OH})$ was found to be near the central estimate of Prather et al. (2001), and close to the model average in the same inter-comparison; this suggests that the $\mathrm{OH}$ source term is approximately correct. It may be that the second largest $\mathrm{O}_{3}$ sink (reaction with $\mathrm{HO}_{2}$ ) is overestimated by the model this may tie in with the potentially over-active hydrocarbon chemistry suggested by the high PAN levels. At this stage, we do not fully understand the low $\mathrm{O}_{3}$ bias in the tropics. In the mid-latitudes this bias is smaller and is confined to the LT and MT.

These model comparisons against observations indicate the model has some skill in simulating $\mathrm{NO}_{\mathrm{x}}, \mathrm{PAN}$ and $\mathrm{O}_{3}$, but also has some significant biases. Nevertheless, the model is generally within \pm 1 standard deviation of observations, and represents a comparable model to others used for similar studies to assess the influence of convective mixing upon $\mathrm{O}_{3}$ and its precursors.

\subsection{Influence of convection over tropical land and ocean}

Figure 3 depicts annual zonal mean tropical $\mathrm{O}_{3}$ and $\mathrm{NO}_{\mathrm{x}}$ concentrations for tropical land and ocean regions separately (Figs. 3a-d) for the control experiment (i.e. normal convective mixing) and the impact of switching on convective mixing (Figs. 3e-h). Many of the features described below can be seen in the model profiles in Fig. 2. For simplicity we discuss Fig. 3 results alone below.

Both species are generally higher over land, where the main $\mathrm{NO}_{\mathrm{x}}$ surface and UT lightning sources are located. The $\mathrm{O}_{3}$ lifetime and production efficiency increase with height these factors, in conjunction with the stratospheric source of 

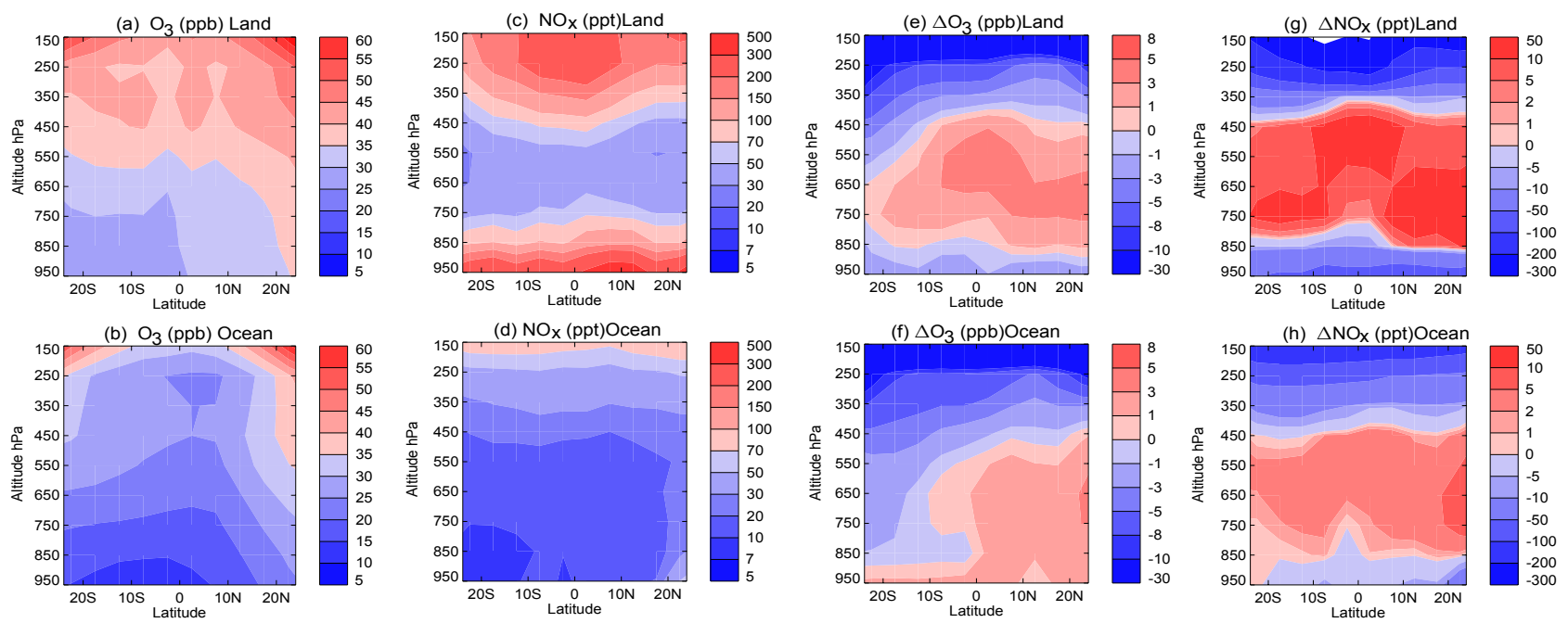

Fig. 3. 20-year average tropical land and ocean $\mathrm{O}_{3}(\mathrm{ppb})(\mathbf{a}, \mathbf{b})$ and $\mathrm{NO}_{\mathrm{x}}(\mathrm{ppt})(\mathbf{c}, \mathbf{d})$ for the control simulation and $\mathrm{O}_{3}(\mathbf{e}, \mathbf{f})$ and $\mathrm{NO}_{\mathrm{x}}(\mathbf{g}, \mathbf{h})$ differences control - convection off simulations.

$\mathrm{O}_{3}$ - produce the $\mathrm{O}_{3}$ gradient from the surface $(25-35 \mathrm{ppb}$ over land, $10-25 \mathrm{ppb}$ over oceans) to the UT (40-60 ppb over land, $30-55 \mathrm{ppb}$ over oceans) (Figs. 3a-b). There are comparable $\mathrm{NO}_{\mathrm{x}}$ mixing ratios in the $\mathrm{LT}$ and UT over land ("C"-shaped profile - Fig. 3c; above 100 ppt in the LT and UT). Over the oceans UT $\mathrm{NO}_{\mathrm{x}}$ is also high (Fig. 3d). Based on the large land/ocean lightning ratio we assume that high values of UT $\mathrm{NO}_{\mathrm{x}}$ over the oceans arises from advection of UT land lightning $\mathrm{NO}_{\mathrm{x}}$ emissions (with a small contribution from lightning over the oceans, Sect. 2).

Both land and ocean regions show large decreases in UT $\mathrm{O}_{3}(10-30 \mathrm{ppb})$ and $\mathrm{NO}_{\mathrm{x}}$ (up to $100-300$ ppt over land; 50$200 \mathrm{ppt}$ over the ocean) due to convection (Figs. 3e-h). LT $\mathrm{O}_{3}$ and $\mathrm{NO}_{\mathrm{x}}$ also decrease over land regions (1-3 ppb and 10-100 ppt, respectively, Figs. 3e, g), but show divergent behaviour over the ocean, where $\mathrm{O}_{3}$ increases slightly $(0-$ $3 \mathrm{ppb}$ ), whilst $\mathrm{NO}_{\mathrm{x}}$ decreases slightly (5-10 ppt) (Figs. 3f, h). Conversely, $\mathrm{MT} \mathrm{O}_{3}$ and $\mathrm{NO}_{\mathrm{x}}$ generally increase over land (by $0-5 \mathrm{ppb}$ and 2-50 ppt, Figs. 3e, g), and over the oceans north of $10^{\circ} \mathrm{S}$. Over the remote oceans, south of $10^{\circ} \mathrm{S}, \mathrm{MT} \mathrm{O}_{3}$ decreases $(0-5 \mathrm{ppb})$ and $\mathrm{MT} \mathrm{NO} \mathrm{N}_{\mathrm{x}}$ increases slightly $(0-5 \mathrm{ppt})$ (Figs. 3f, h).

Figure 4 displays vertical changes in tropical $\mathrm{O}_{3}$ chemical production and destruction when convective mixing is switched on. Since $\mathrm{NO}$ is the main species involved in $\mathrm{O}_{3}$ production, the changes in $\mathrm{O}_{3}$ chemical production with convective mixing are generally similar to that of $\mathrm{NO}_{\mathrm{x}}$ changes (compare Figs. $4 \mathrm{a}-\mathrm{b}, 3 \mathrm{~g}-\mathrm{h}$ ). However there are some differences. In particular, UT $\mathrm{O}_{3}$ production increases over land, whereas $\mathrm{NO}_{\mathrm{x}}$ decreases, and surface decreases are large. $\mathrm{O}_{3}$ chemical destruction is primarily determined by water vapour concentrations and the $\mathrm{O}_{3}$ vertical distribution (mainly through the $\mathrm{H}_{2} \mathrm{O}+\mathrm{O}\left({ }^{1} \mathrm{D}\right)$ reaction). As water vapour concentrations do not change between experiments (Sect. 2), the changes in $\mathrm{O}_{3}$ chemical destruction are similar to the changes in $\mathrm{O}_{3}$ (compare Figs. $4 \mathrm{c}-\mathrm{d}, 3 \mathrm{e}-\mathrm{f}$ ), although again there are some differences. Net $\mathrm{O}_{3}$ chemical production increases in the MT and UT, and decreases at the surface over land (Fig. 4e). Over the oceans, net $\mathrm{O}_{3}$ production decreases at the surface and in the UT, and in the MT increases over remote regions but decreases elsewhere (Fig. 4f).

The effects of convection on $\mathrm{NO}_{\mathrm{x}}$ can partly be understood in terms of a flattening of the tropical land " $\mathrm{C}$ "-shaped profile (Fig. 2a), and we assume advection of this effect of over the oceans (Figs. 2a, b, 3a, b). This partly occurs in our model as UT $\mathrm{NO}_{\mathrm{x}}$ from lightning emissions is displaced to lower altitudes, and surface $\mathrm{NO}_{\mathrm{x}}$ emissions are lifted to higher altitudes, which results in higher $\mathrm{NO}_{\mathrm{x}}$ concentrations in the MT (Figs. 3g-h). However, the UT $\mathrm{NO}_{\mathrm{x}}$ decreases over land are larger than $\mathrm{NO}_{\mathrm{x}}$ increases in the MT by an order of magnitude, suggesting that mixing of $\mathrm{NO}_{\mathrm{x}}$ is not the only factor influencing $\mathrm{NO}_{\mathrm{x}}$ concentrations (Figs. 3g-h). As discussed in Sect. 1, convection also affects non-methane hydrocarbons (NMHCs) including isoprene, lifting these gases and their degradation products into the UT (Collins et al., 1999). Isoprene has a very short lifetime $(<1 \mathrm{~h}$; Seinfeld and Pandis, 1997), and is emitted in substantial quantities from tropical vegetation (Guenther et al., 1995; Sanderson et al., 2003b). The natural source of isoprene is much larger than the mainly anthropogenic sources of other NMHCs in the tropics. Here, the prevalence of isoprene, together with its short lifetime, means that its distribution is strongly affected by convection. Figure 5a shows that convection increases MT and UT isoprene at the expense of surface; these changes are largest over equatorial land. Convective lifting of isoprene brings the peroxy acetyl radical $\left(\mathrm{CH}_{3} \mathrm{COO}_{2}\right)$, an isoprene degradation product, into contact with lightning $\mathrm{NO}_{\mathrm{x}}$. This leads to significant PAN formation in the cold UT over equatorial land 

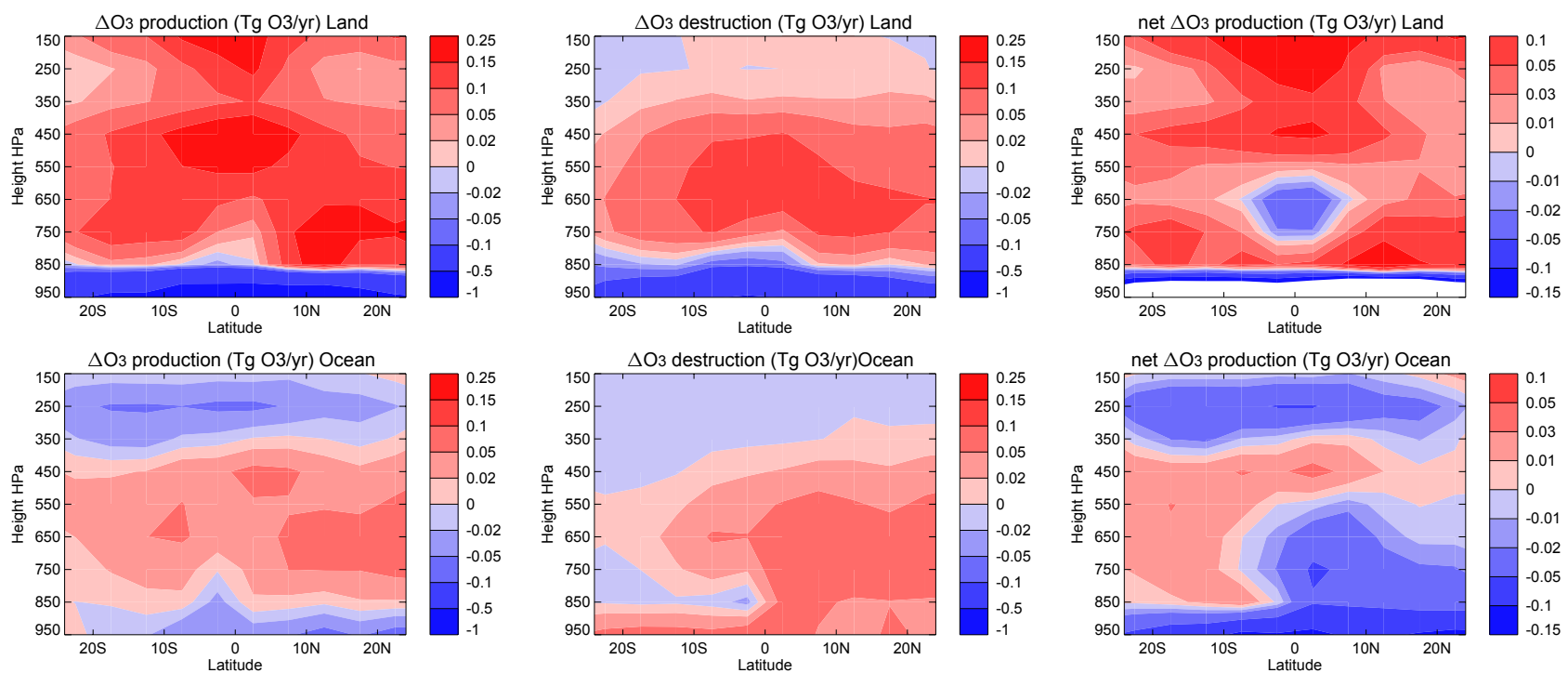

Fig. 4. 20-year average tropical land and ocean $\mathrm{O}_{3}$ production $(\mathbf{a}, \mathbf{b}), \mathrm{O}_{3}$ destruction (c, d) and net $\mathrm{O}_{3}$ chemical production $\left(\mathbf{e}\right.$, f) (Tg $\left.\mathrm{O}_{3}\right)$ control-convection off simulations.
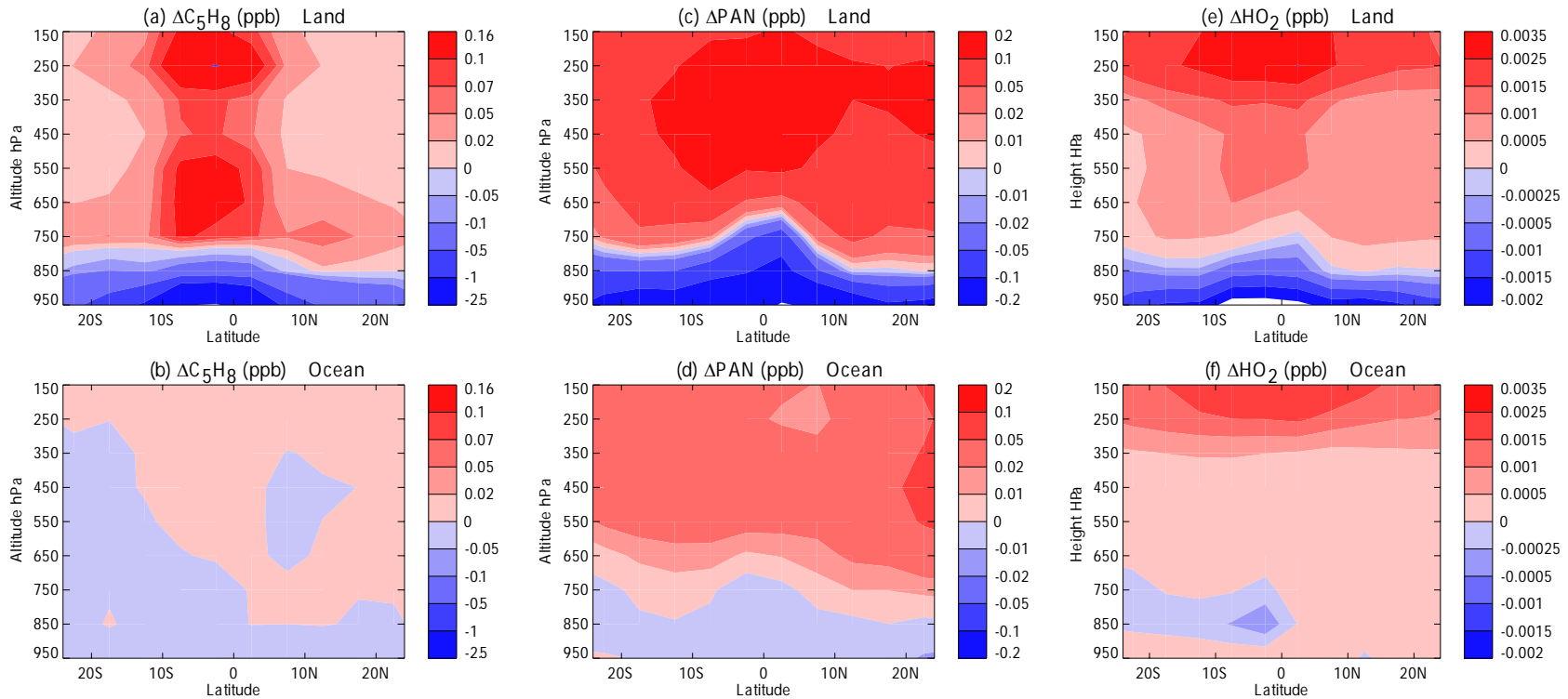

Fig. 5. 20-year average tropical land and ocean isoprene (a, b), PAN (c, d) and $\mathrm{HO}_{2}(\mathbf{e}, \mathbf{f})$ differences (ppb) control-convection off simulations.

at the expense of $\mathrm{NO}_{\mathrm{x}}$ (Figs. $5 \mathrm{c}, 3 \mathrm{~g}$ ). We suspect the higher UT PAN and lower UT $\mathrm{NO}_{\mathrm{x}}$ concentrations over the oceans result from these changes over land (Fig. 5d). In parallel sensitivity experiments with no lightning $\mathrm{NO}_{\mathrm{x}}$ emissions we find that the impact of convective mixing, in terms of tropical PAN increases, is reduced by $\sim 50 \%$. This indicates that convected isoprene is a significant source of PAN in the UT. PAN acts as a reservoir for $\mathrm{NO}_{\mathrm{x}}$, and its breakdown to release stored $\mathrm{NO}_{\mathrm{x}}$ is strongly temperature dependent - in the cold UT PAN is relatively stable and has a lifetime of the or- der of months. Comparing changes in $\mathrm{NO}_{\mathrm{x}}$ and PAN in the UT $(350-150 \mathrm{hPa})$ we find UT $\mathrm{NO}_{\mathrm{x}}$ decreases by $0.032 \mathrm{Tg} \mathrm{N}$ (50\% decrease) and a UT PAN increases by $0.028 \mathrm{Tg} \mathrm{N}(65 \%$ increase). In terms of $\mathrm{N}$ conservation we therefore expect that a substantial fraction of the $\mathrm{NO}_{\mathrm{x}}$ decrease arises from the PAN increase. Thus the impact of convection on $\mathrm{NO}_{\mathrm{x}}$ is through convective transport of $\mathrm{NO}_{\mathrm{x}}$ itself in combination with isoprene-PAN-NO ${ }_{x}$ chemistry in the UT. 


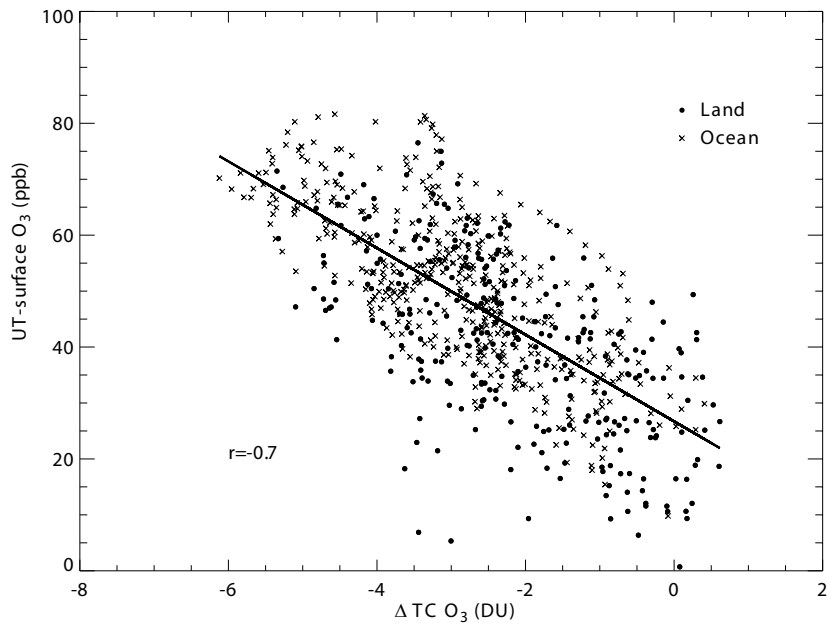

Fig. 6. 20-year annual-average change in $\mathrm{TTC} \mathrm{O}_{3}$ (DU) (controlconvection off) vs. UT (350-150 hPa) - surface (950 hPa) $\mathrm{O}_{3}(\mathrm{ppb})$ (convection off experiment) for combined tropical land and ocean grid boxes.

For $\mathrm{O}_{3}$, as discussed above for $\mathrm{NO}_{\mathrm{x}}$, upward transport of $\mathrm{LT}$ air over land and ocean displaces $\mathrm{UT} \mathrm{O}_{3}$-rich air, which subsides downwards. Over land, similar to $\mathrm{NO}_{\mathrm{x}}$, convection moves $\mathrm{O}_{3}$ away from its source regions, raising MT concentrations. Therefore vertical mixing of the $\mathrm{O}_{3}$ profile itself, as well as changes in the $\mathrm{NO}_{\mathrm{x}}$ distribution, cause the changes in the $\mathrm{O}_{3}$ distribution over polluted land. However, changes in UT $\mathrm{NO}_{\mathrm{x}}$ over land contrast with changes in UT $\mathrm{O}_{3}$ production over land. Despite a large reduction in UT $\mathrm{NO}_{\mathrm{x}}$ (Fig. 3g) with convective mixing, UT O 3 production increases (Fig. 4a). The role of isoprene is again important here, as its oxidation generates peroxy radicals $\left(\mathrm{HO}_{2}\right.$ and $\mathrm{RO}_{2}$ ), which are required for $\mathrm{O}_{3}$ production. $\mathrm{O}_{3}$ production in the tropical UT tends to fall due to the reduction in UT $\mathrm{NO}_{\mathrm{x}}$, but this effect is more than offset by an increase in $\mathrm{UT} \mathrm{HO}_{2}$ produced from isoprene (Figs. 5e, f). As $\mathrm{HO}_{2}$ also destroys $\mathrm{O}_{3}$, the $\mathrm{HO}_{2}$ increases explain the small equatorial land $\mathrm{UT}_{3}$ destruction increases (Fig. 4c). Despite an overall increase in net chemical production in the UT, $\mathrm{O}_{3}$ decreases. This indicates that vertical transport of $\mathrm{O}_{3}$ itself is more important than changes in chemistry in determining the outcome of convective mixing in the UT. Over the remote southern oceans, MT $\mathrm{O}_{3}$ decreases and surface $\mathrm{O}_{3}$ increases in contrast to $\mathrm{NO}_{\mathrm{x}}$ and $\mathrm{O}_{3}$ production changes. This also implies that over remote tropical locations vertical transport of $\mathrm{O}_{3}$ itself is more important than changes in $\mathrm{NO}_{\mathrm{x}}$ chemistry.

To summarise, convection therefore influences modelled $\mathrm{O}_{3}$ distributions by a combination of vertical transport of $\mathrm{O}_{3}$, as well as by affecting the vertical distribution of its precursors, especially $\mathrm{NO}_{\mathrm{x}}$ and $\mathrm{HO}_{2}$ and the resultant chemical production and destruction of $\mathrm{O}_{3}$. Vertical transport appears to be the dominant process in clean air, over the remote oceans in the MT and LT, and in polluted land regions in the UT.
Elsewhere both convective transport and chemistry changes contribute significantly to the overall impact of convection on the $\mathrm{O}_{3}$ distribution. The impact of convective mixing is summarized in Table 2.

To assess the influence of vertical transport on the $\mathrm{O}_{3}$ distribution the relationship between the $\mathrm{O}_{3}$ gradient in the convection off experiment and the change in TTC $\mathrm{O}_{3}$ due to convection was examined for all grid boxes over the tropics (Fig. 6). A strong correlation was found ( $\mathrm{r}=0.7)$. For each $10 \mathrm{ppb}$ steepening in the $\mathrm{O}_{3}$ gradient between the UT (350$150 \mathrm{hPa})$ and surface $(950 \mathrm{hPa})$, convection reduces TTC $\mathrm{O}_{3}$ by $1.5 \mathrm{DU}$ (Fig. 6). The relationship is stronger if the change in $\mathrm{UT} \mathrm{O}_{3}$ alone is considered ( $\mathrm{r}=0.9$, not shown). This also suggests that vertical transport of $\mathrm{O}_{3}$ plays a major role in the resultant $\mathrm{O}_{3}$ distribution after convection, particularly in the UT.

\subsection{Influence of convection in the extra-tropics}

Deep convective mixing has a global effect on $\mathrm{O}_{3}$ distributions (Fig. 7a). UT $\mathrm{O}_{3}$ not only decreases in the tropics but also decreases by similar amounts in the mid-latitudes and polar regions $(10-30 \mathrm{ppb})$.

Over the northern mid-latitudes (Fig. 1) some deep convection reaches the UT, especially over parts of the North American and Asian continents. Examination of the largescale flow in HadAM3 suggests that the large tropical anomalies may also be transported latitudinally, and downward along the subtropical front in the northern mid-latitudes. Consequently, both latitudinal transport and convective mixing in the northern mid-latitudes are likely to contribute to the simulated $\mathrm{UT} \mathrm{O}_{3}$ decreases. In the southern mid-latitudes, some deep convection also occurs over the southern oceans (Fig. 1). We suspect this is the main cause of UT O $\mathrm{O}_{3}$ decreases in the southern hemisphere.

The slightly lower $\mathrm{O}_{3}$ stratospheric influx when convective mixing is switched on (Table 1) may also contribute to lower extra-tropical UT $\mathrm{O}_{3}$. Convective mixing also influences $\mathrm{NO}_{\mathrm{x}}$ distributions well outside the tropics (Fig. $7 \mathrm{~b}$ ). The changes are highly skewed towards the Northern Hemisphere reflecting the large surface $\mathrm{NO}_{\mathrm{x}}$ emissions in this region. Tropical UT $\mathrm{NO}_{\mathrm{x}}$ decreases $(100-200 \mathrm{ppt})$ are transported latitudinally, which together with mid-latitude convection results in negative $\mathrm{UT} \mathrm{NO}_{\mathrm{x}}$ anomalies extending to $45^{\circ}$ in the Northern Hemisphere.

In northern mid-latitudes, convection generally reduces surface $\mathrm{O}_{3}$ and $\mathrm{NO}_{\mathrm{x}}$ (except for $\mathrm{O}_{3}$ around $60^{\circ} \mathrm{N}$ ), which reflects enhanced venting of polluted continental $\mathrm{NO}_{\mathrm{x}}$ and $\mathrm{O}_{3}$-rich air by shallow convection (Figs. 7a, b). The increase of $\mathrm{O}_{3}$ accompanied by a large decrease of $\mathrm{NO}_{\mathrm{x}}(100-200 \mathrm{ppt})$ around $60^{\circ} \mathrm{N}$ is the titration effect which occurs over NorthWestern Europe. This effect occurs under very high $\mathrm{NO}_{x}$ levels predominantly in winter (when there are low UV levels for $\mathrm{NO}_{2}$ photolysis) whereby $\mathrm{NO}$ reacts with $\mathrm{O}_{3}$ to form $\mathrm{NO}_{2}$. Thus with convective mixing, surface air low in $\mathrm{O}_{3}$ 
(a) $\Delta 03(\mathrm{ppb})$

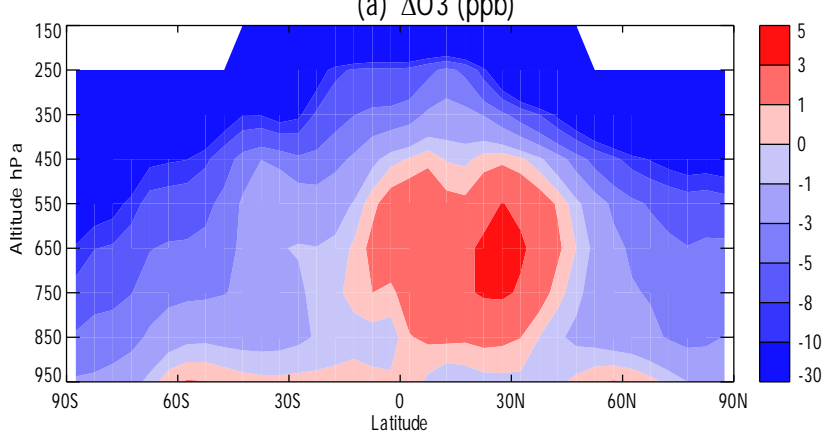

(b) $\triangle \mathrm{NOX}(\mathrm{ppb})$

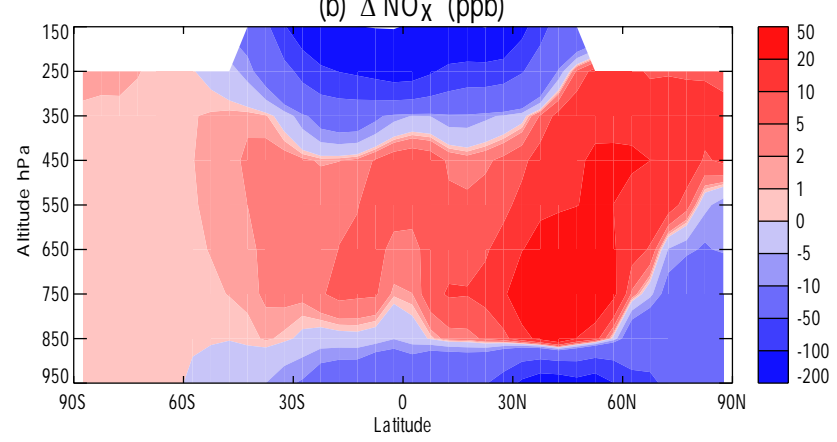

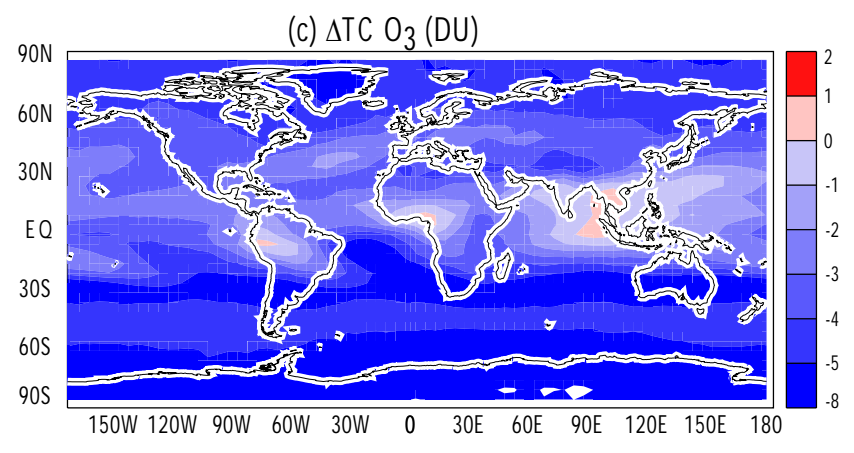

(d) $\Delta$ Column-Average $\mathrm{NO}$ (ppt)

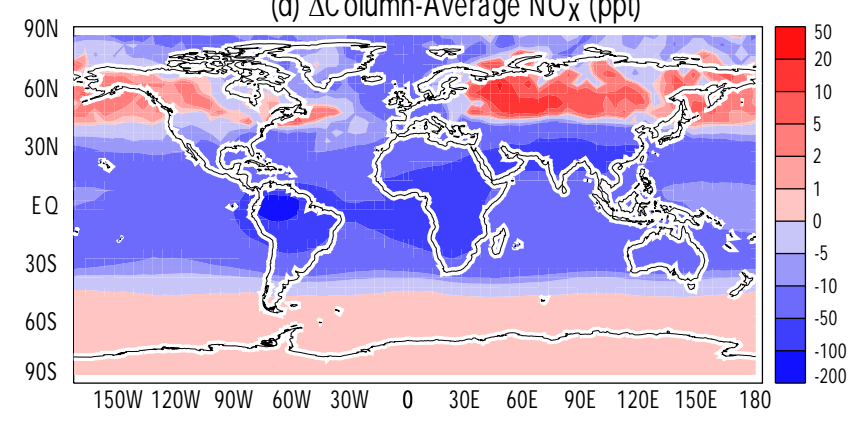

Fig. 7. 20-year average global change in $\mathrm{O}_{3}$ (ppb) (a) $\mathrm{NO}_{\mathrm{x}}$ (ppt) (b) $\mathrm{TC} \mathrm{O}_{3}$ (DU) (c) and column-average $\mathrm{NO}_{\mathrm{x}}$ (ppt) (d) for control convection off simulations.

and high in $\mathrm{NO}_{\mathrm{x}}$ is replaced by air with higher $\mathrm{O}_{3}$ and lower $\mathrm{NO}_{\mathrm{x}}$ concentrations. In the polar regions, large-scale subsidence of UT air, that is less rich in $\mathrm{O}_{3}$ due to hemispheric transport, results in lower surface $\mathrm{O}_{3}$. At northern polar latitudes LT $\mathrm{NO}_{\mathrm{x}}$ levels are highest during winter months and the impact of convective mixing is largest. Shallow convection that lifts $\mathrm{NO}_{\mathrm{x}}$ upwards from the LT and MT, combined with transport of the mid-latitudinal anomaly generates negative LT/MT $\mathrm{NO}_{\mathrm{x}}$ anomalies over the Arctic (Fig. 7b). In the southern mid-latitudes as in the southern tropics, where precursor emissions are lesser, surface $\mathrm{O}_{3}$ increases and $\mathrm{NO}_{\mathrm{x}}$ decreases slightly.

MT $\mathrm{O}_{3}$ increases in the northern mid-latitudes up to around $40^{\circ} \mathrm{N}$, as in the northern tropics, but decreases elsewhere in the mid-latitudes and polar regions. We suspect that large scale subsidence of large UT anomalies dominates the vertical $\mathrm{O}_{3}$ distribution (Fig. 7a). Convection produces strong MT $\mathrm{NO}_{\mathrm{x}}$ increases (10-50 ppt) in the northern midlatitudes at the expense of the surface (Fig. 7b). These midlatitudinal $\mathrm{MT} \mathrm{NO}_{\mathrm{x}}$ increases appear to be transported to the remote troposphere.

In the column average, convective overturning leads to tropospheric column (TC) $\mathrm{O}_{3}$ decreases almost everywhere (Fig. 7c). Decreases are largest (up to 8DU) over the clean southern ocean regions where surface $\mathrm{O}_{3}$ concentrations are lowest and therefore the effects of deep convection that reaches the UT are presumably greatest. Over equato- rial land regions, where $\mathrm{MT} \mathrm{O}_{3}$ increases are greatest, TC $\mathrm{O}_{3}$ decreases are smallest (0-2 DU) and in small areas above strong $\mathrm{NO}_{\mathrm{x}}$ source regions (e.g., SE Asia) $\mathrm{TC} \mathrm{O}_{3}$ increases slightly (0-1 DU). Tropospheric column-average $\mathrm{NO}_{\mathrm{x}}$ also decreases (strongly) over tropical land regions (50-100 ppt, Fig. 7d) and outflow oceanic regions. The northern midlatitudes show increases over land and Pacific regions with the largest changes (10-50 pptv, Fig. 7d) over western Eurasia, reflecting upward mixing in convective regions.

As over tropical land, chemical $\mathrm{O}_{3}$ production increases in the northern mid-latitudes in the MT and UT and decreases strongly at the surface over both land and ocean to $\sim 45^{\circ} \mathrm{N}$, reflecting $\mathrm{NO}_{\mathrm{x}}$ changes (not shown). $\mathrm{O}_{3}$ chemical destruction exhibits similar behaviour as in the tropics (not shown). It decreases at the surface over land and increases over oceans, and increases in the MT; UT changes are small. These changes weaken with higher latitude, reflecting the $\mathrm{O}_{3}$ distribution changes. Overall net chemical $\mathrm{O}_{3}$ production increases in the MT and UT, with the largest changes between $30^{\circ}-45^{\circ} \mathrm{N}$, where there is some $\mathrm{O}_{3}$ chemical production, but little destruction. Table 2 provides a summary of the impact of convective mixing over polluted regions between $30^{\circ} \mathrm{S}-$ $45^{\circ} \mathrm{N}$ and remote oceanic regions. 
Table 1. 20-year average $\mathrm{O}_{3}$ budget changes (control - convection off).

\begin{tabular}{|c|c|c|c|c|c|c|c|c|}
\hline $\begin{array}{l}\text { Budget term } \\
\mathrm{Tg}\left(\mathrm{O}_{3}\right) / \mathrm{yr}\end{array}$ & $\begin{array}{c}20 \text {-year average } \\
\text { control } \\
\text { Mask }=\mathrm{O}_{3}>150 \mathrm{ppb}\end{array}$ & $\begin{array}{c}20 \text {-year average } \\
\text { convection off } \\
\text { Mask }=\mathrm{O}_{3}>150 \mathrm{ppb}\end{array}$ & $\begin{array}{c}\% \text { change with } \\
\text { convective mixing } \\
\text { Mask }=\mathrm{O}_{3}>150 \mathrm{ppb}\end{array}$ & $\begin{array}{c}\text { 20-year average } \\
\text { control } \\
\text { Mask=PT }\end{array}$ & $\begin{array}{c}\text { 20-year average } \\
\text { convection off } \\
\text { Mask=PT }\end{array}$ & $\begin{array}{c}\% \text { change with } \\
\text { convective mixing } \\
\text { Mask=PT }\end{array}$ & $\begin{array}{l}\text { Lawrence } \\
\text { et al. ( } 2003) \\
\% \text { change }\end{array}$ & $\begin{array}{c}\text { Lelieveld } \\
\text { and Crutzen (1994) } \\
\% \text { change }\end{array}$ \\
\hline $\mathrm{O}_{3}$ chemical production & $4712(86)$ & 4547 (108) & +3.6 & $4709(87)$ & 4541 (108) & +3.7 & +16.7 & +14 \\
\hline $\mathrm{O}_{3}$ chemical destruction & $4224(84)$ & 4097 (102) & +3.0 & $4223(84)$ & $4096(103)$ & +3.0 & +15.0 & +22 \\
\hline $\mathrm{O}_{3}$ net chemical production & 489 (15) & $450(21)$ & +8.6 & $487(15)$ & $446(21)$ & +9.1 & +81.8 & -25 \\
\hline $\mathrm{O}_{3}$ dry deposition & $881(7)$ & $851(13)$ & +3.5 & $881(7)$ & $851(13)$ & +3.5 & +7.0 & +15 \\
\hline $\mathrm{O}_{3}$ stratospheric influx & $392 *(15)$ & $401^{*}(21)$ & -2.2 & $395 *(15)$ & $405^{*}(21)$ & -2.6 & -2.1 & \\
\hline $\mathrm{O}_{3}$ burden $\left(\mathrm{Tg} \mathrm{O}_{3}\right)$ & $250(3)$ & $289(6)$ & -13.8 & $243(3)$ & $281(6)$ & -13.4 & +11.9 & -20 \\
\hline $\mathrm{O}_{3}$ lifetime (days) & $17.8(0.2)$ & $21.2(0.4)$ & -16.2 & $17.3(0.2)$ & $20.7(0.4)$ & -15.8 & -2.5 & \\
\hline $\mathrm{NO}_{\mathrm{x}}$ burden $(\mathrm{Tg} \mathrm{N})$ & $0.153(0.002)$ & $0.194(0.006)$ & -27.5 & $0.151(0.002)$ & $0.192(0.006)$ & -21.2 & +14 & -30 \\
\hline $\mathrm{No}_{\mathrm{x}}$ lifetime (days) & $1.1^{+}$ & $1.4^{+}$ & -21.6 & & & & & \\
\hline PAN burden (Tg N) & $0.320(0.006)$ & $0.264(0.007)$ & +21.2 & $0.319(0.006)$ & $0.263(0.007)$ & +21.4 & & \\
\hline $\mathrm{OH}$ burden $(\mathrm{Tg} \mathrm{OH})$ & $203(4)$ & $187(3)$ & +8.3 & $201(4)$ & $186(3)$ & +8.5 & & \\
\hline
\end{tabular}

* not significantly different at the 0.01 level.

+ This is the $\mathrm{NO}_{\mathrm{x}}$ lifetime change for the entire model domain-surface up to $100 \mathrm{hPa}$. We do not archive sufficient 3-D fluxes to be able to calculate the $\mathrm{NO}_{\mathrm{x}}$ lifetime using a tropopause mask.

$\mathrm{O}_{3}$ chemical production reactions are: $\mathrm{NO}+\mathrm{HO}_{2}, \mathrm{NO}+\mathrm{CH}_{3} \mathrm{O}_{2}, \mathrm{NO}+\mathrm{RO}_{2}$.

$\mathrm{O}_{3}$ chemical destruction reactions are: $\mathrm{O}^{1} \mathrm{D}+\mathrm{H}_{2} \mathrm{O}, \mathrm{O}_{3}+\mathrm{OH}, \mathrm{O}_{3}+\mathrm{HO}_{2}, \mathrm{O}_{3}$ thydrocarbons $\left(\mathrm{C}_{2} \mathrm{H}_{4}, \mathrm{C}_{3} \mathrm{H}_{6}(2\right.$ routes $), \mathrm{C}_{5} \mathrm{H}_{8}, \mathrm{Methyl}$ vinyl ketone) and other minor net $\mathrm{O}_{3}$ losses.

\subsection{Influence of convection on the global tropospheric $\mathrm{O}_{3}$ budget}

Global tropospheric budgets for $\mathrm{O}_{3}$ with and without convective mixing are calculated in Table 1.

The global budgets have been calculated using two different masking techniques in order to assess uncertainty arising from use of the $150 \mathrm{ppb}$ isopleth to determine the tropopause. The first 3 columns in Table 1 show results using the $150 \mathrm{ppb}$ tropopause definition, and the next three columns show results using the HadAM3 physical tropopause. As discussed in Sect. 2, the same mask is used in the control and convection off simulations. The 20-year annual-average budget terms are calculated to be similar for the two tropopause definitions, thus the values given below are based on the physical tropopause definition. Annual-average standard deviations are also tabulated. Larger interannual variability occurs in the convection off simulation. This is presumably due to steeper concentration gradients through the troposphere in the absence of convective mixing.

Chemical production increases globally by $3.7 \%$, mainly due to tropical and northern mid-latitudinal $\mathrm{MT} \mathrm{NO}_{\mathrm{x}}$ increases (Figs. 7b, 4a). Global chemical destruction also increases (by 3.0\%) as a result of $\mathrm{MT} \mathrm{O}_{3}$ increases (Figs. 7a, $4 \mathrm{c})$. Because net chemical production is the small residual of two large budget terms it has a relatively large increase of $9.1 \%$. Dry deposition (which increases with surface $\mathrm{O}_{3}$ ) globally increases by $3.5 \%$. All annual-average $\mathrm{O}_{3}$ fluxes are significantly different (at the 0.01 level) between the control and convection off simulations, bar stratospheric input (Table 1). Despite increased global net chemical production due to tropical MT increases, the global $\mathrm{O}_{3}$ burden decreases by $13.4 \%$. Likewise, the $\mathrm{O}_{3}$ lifetime decreases globally from
20.7 to 17.3 days $(15.8 \%)$. The global $\mathrm{NO}_{\mathrm{x}}$ burden also decreases globally by $21.2 \%$ and PAN increases by a similar amount.We estimate that the $\mathrm{NO}_{\mathrm{x}}$ lifetime decreases by $\sim 20 \%$ with convective mixing; mainly due to the downward transport of lightning $\mathrm{NO}_{\mathrm{x}}$ emissions (since there are lightning $\mathrm{NO}_{\mathrm{x}}$ emissions in the convection off case). The $\mathrm{OH}$ burden increases by $8.5 \%$ as a result of greater $\mathrm{O}_{3}$ destruction (and hence $\mathrm{OH}$ production) with convective mixing. The differences in burdens between the control and convection off experiments are significant at the 0.01 level for all species mentioned above.

\section{Discussion}

Lelieveld and Crutzen (1994) calculated a $20 \%$ decrease in the global $\mathrm{O}_{3}$ burden due to convective mixing, using a global model with no NMHC chemistry. In their model, they found that the effects of mixing $\mathrm{O}_{3}$ over-rode any chemical effects due to mixing of $\mathrm{O}_{3}$ precursors. More recently, Lawrence et al. (2003), using a global model with detailed NMHC chemistry (similar to that used in this study), found a global $\mathrm{O}_{3}$ burden increase of $12 \%$ from convective mixing. In their study, Lawrence et al. (2003) found the effects of changes in precursor chemistry due to mixing (in particular lifting of surface $\mathrm{NO}_{\mathrm{x}}$ emissions) to outweigh the effect of vertical mixing of $\mathrm{O}_{3}$ itself. In our study with the STOCHEM-HadAM3 model, $\mathrm{O}_{3}$ decreases by $13 \%$ due to convective mixing, and the effect of $\mathrm{O}_{3}$ vertical transport outweighs the effect of precursor mixing changes (Table 1; Fig. 7a). Differences in the patterns of $\mathrm{TC} \mathrm{O}_{3}$ change are large with decreases almost everywhere in our study, compared to increases everywhere in Lawrence et al. (2003). 
Table 2. Summary of the impact of convective mixing on polluted and remote regions. The largest impact is in bold print.

\begin{tabular}{|c|c|c|c|}
\hline Process & $\begin{array}{l}\text { Impact on } \mathrm{O}_{3} \\
\text { over polluted land } \\
\left(45^{\circ} \mathrm{N}-15^{\circ} \mathrm{S}\right)\end{array}$ & $\begin{array}{l}\text { Impact on } \mathrm{O}_{3} \\
\text { over remote oceans } \\
\left(0^{\circ}-60^{\circ} \mathrm{S}\right)\end{array}$ & Dominant impact \\
\hline Convective transport of $\mathrm{O}_{3}$ & $\begin{array}{l}\mathrm{UT} \mathrm{O}_{3} \downarrow \\
\mathrm{MT} \mathrm{O}_{3} \uparrow \\
\text { Surface } \mathrm{O}_{3} \downarrow\end{array}$ & $\begin{array}{l}\mathrm{UT} \mathrm{O}_{3} \downarrow \\
\mathrm{MT} \mathrm{O}_{3} \downarrow \\
\text { Surface } \mathrm{O}_{3} \uparrow\end{array}$ & $\begin{array}{l}\text { Overall TCO decreases } \\
\text { except in parts } \\
\text { of SE Asia }\end{array}$ \\
\hline $\begin{array}{l}\text { Convective transport of } \mathrm{NO}_{\mathrm{x}} \\
\text { n.b. lightning emissions in both simulations }\end{array}$ & $\begin{array}{l}\mathrm{UT} \mathrm{NO}_{\mathrm{x}} \downarrow \\
\mathrm{MT} \mathrm{NO}_{\mathrm{x}} \uparrow \\
\text { Surface } \mathrm{NO}_{\mathrm{x}} \downarrow\end{array}$ & $\begin{array}{l}\mathrm{UT} \mathrm{NO}_{\mathrm{x}} \downarrow \\
\text { MT NO} \mathrm{NO}_{\mathrm{x}} \uparrow \\
\text { Surface } \mathrm{NO}_{\mathrm{x}} \downarrow\end{array}$ & $\begin{array}{l}\text { Largest changes over } \\
\text { polluted regions and in the UT } \\
\mathrm{UT} \mathrm{O}_{3} \text { Production } \downarrow \\
\mathrm{MT} \mathrm{O}_{3} \text { Production } \uparrow \\
-\left(\text { largest changes } 30^{\circ}-60^{\circ} \mathrm{N}\right) \\
\text { Surface } \mathrm{O}_{3} \text { Production } \downarrow \\
\left.\text { - (largest changes } 30^{\circ}-60^{\circ} \mathrm{N}\right)\end{array}$ \\
\hline Convected $\mathrm{C}_{5} \mathrm{H}_{8} \Rightarrow \mathrm{HO}_{2}+\mathrm{RO}_{2}$ & $\begin{array}{l}\mathrm{UT} \mathrm{O}_{3} \text { Production } \uparrow \\
\mathrm{UT} \mathrm{O} \mathrm{O}_{3} \text { destruction } \uparrow\end{array}$ & & UT Net $\mathrm{O}_{3}$ production $\uparrow$ \\
\hline Convected $\mathrm{C}_{5} \mathrm{H}_{8} \Rightarrow \mathrm{NO}_{\mathrm{x}}$ to PAN conversion & $\mathrm{UT} \mathrm{NO}_{\mathrm{x}} \downarrow$ & & $\mathrm{UT} \mathrm{O}_{3}$ Production $\downarrow$ \\
\hline
\end{tabular}

One similarity between the Lawrence et al. (2003) and this study is that $\mathrm{MT} \mathrm{O}_{3}$ increases due to mixing of precursor $\mathrm{NO}_{\mathrm{x}}$ emissions. Lawrence et al. (2003) also report $\mathrm{O}_{3}$ budgets for their simulations. In common with this study, they find that switching on convection results in an increase in production of $\mathrm{O}_{3}$, although they find a larger percentage increase (Table 1). Another similarity is that convection reduces the tropospheric $\mathrm{O}_{3}$ lifetime. The impact of convective mixing on tropospheric $\mathrm{O}_{3}$ lifetime is much stronger in our study. As discussed in Sect. 3.1, of all the models sampled in a recent intercomparison (Stevenson et al., 2005b), STOCHEM-HadAM3 had the shortest lifetime (17 days), whereas MATCH-MPIC had the longest (28 days).We might therefore expect some significant differences in the responses of these two models to convection, even if the convective mass fluxes were quite similar. With the larger reduction in tropospheric $\mathrm{O}_{3}$ lifetime, the tropospheric $\mathrm{O}_{3}$ burden falls in our study, whereas Lawrence et al. find an increase. The reduction in lifetime in our results arises mainly due to a reduction in $\mathrm{UT} \mathrm{O}_{3}$ concentrations. In our model these $\mathrm{UT} \mathrm{O}_{3}$ reductions are driven mainly by the vertical mixing of $\mathrm{O}_{3}$, as we find they occur despite increases in land UT chemical production (Fig. 4a). An interesting observation is that land UT chemical production increases despite large reductions in $\mathrm{NO}_{\mathrm{x}}$ (Figs. $4 \mathrm{a}, 3 \mathrm{~g}$ ) - this indicates that $\mathrm{HO}_{\mathrm{x}}$ increases (Figs. 5e, f) outweigh the $\mathrm{NO}_{\mathrm{x}}$ decreases (Figs. 3g, h). In the Lawrence et al. (2003) study UT $\mathrm{O}_{3}$ increases, which suggests that $\mathrm{UT}_{3}$ production increases are greater than in our study.

Do the differences in the impact of convective mixing in these two contemporary models represent a realistic uncer- tainty range? To answer this question we need to understand the root causes of these inter-model differences. Below we investigate potential model differences.

In both studies, the water vapour distribution and lightning $\mathrm{NO}_{\mathrm{x}}$ emissions were kept constant between the control and convection off (or equivalent) simulations.

Differences in the convection schemes themselves (Prather et al., 2001) may be an important, if not the most important cause, of the different effects of convective mixing on the $\mathrm{O}_{3}$ burden in the two studies. In particular, differences in the height and strength of convection (Olivié et al., 2004) and efficiency of vertical transport of $\mathrm{NO}_{\mathrm{x}}$ and $\mathrm{O}_{3}$ out of the boundary layer (Beekman et al., 2003) may be crucial. Annual-average convective updraught mass fluxes simulated in HadAM3 and MATCH-MPIC (Rasch et al., 1997) models are displayed in Fig. 1 for years 1991-1996 and 1995, respectively. Annual-average convective mass fluxes for 19911996 and the year 1995 are similar in HadAM3, showing 1995 to be a typical year within the 1991-1996 period.

The strength of convective updraught fluxes in the tropics and mid-latitudes is typically a factor of 2-3 stronger everywhere in HadAM3 compared to MATCH-MPIC (Figs. 1a-c, $\mathrm{g}-\mathrm{i})$. Whilst HadAM3 has generally stronger and higher convection compared to ERA-40- (Figs. 1a-f), MATCH-MPIC shows weaker and less deep convection (Figs. 1g-i). In particular, there is much less convection in the upper UT in MATCH-MPIC. This implies more vigorous and extensive deep convection in the HadAM3 model. There is general agreement between the two models in the location of convective updraughts in the MT (Figs. 1b, h), except that there is little convection over the Eastern Pacific branch of 
the ITCZ in MATCH-MPIC. In the UT (Figs. 1a, g) there are much greater differences between the simulated convective updraught fluxes. In particular, HadAM3 exhibits much greater convection across the ITCZ, and shows greater deep convection in mid-latitude regions.

Olivié et al. (2004) compared the impact of using convective mass fluxes derived from two different methods on tropospheric $\mathrm{O}_{3}$ distribution. One source of convective mass fluxes was directly archived "on-line" ERA-40 reanalyses, the other a convective parametrisation in the TM3 model based on large-scale wind, temperature, evaporation and humidity fields from ERA-40 reanalyses. In this case convective mass fluxes are derived "off-line". Both derived mass fluxes are based on Tiedtke (1989), but have different modifications to their underlying schemes. The datasets also have different temporal averaging properties (time-averaged vs. instantaneous). One of the main differences reported by Olivié et al. (2004) was that convective mass fluxes reach higher altitudes in the ERA-40 on-line reanalyses compared to those diagnosed off-line. Comparing the results from simulations performed using their on-line and off-line convection schemes Olivié et al. (2004) find lower $\mathrm{O}_{3}$ and $\mathrm{NO}_{\mathrm{x}}$ concentrations in the UT and higher concentrations in the free troposphere as a result of the deeper convection in the ERA-40 on-line scheme. This promoted greater transport of $\mathrm{O}_{3}$-poor air from the surface to the UT, as well as more subsidence to the MT. Therefore, we expect that it is the higher and larger amount of convection that leads to the substantial reduction of tropical $\mathrm{UT} \mathrm{O}_{3}$ in STOCHEM, which is not seen in the MATCH-MPIC simulations. Olivié et al. (2004) also report a reduction in tropical UT $\mathrm{O}_{3}$ concentrations using on-line compared to off-line ERA-40 reanalyses convective mass fluxes. They suggest that these tropical anomalies are transported to higher latitudes through latitudinal transport, and transport downward along the subtropical front. The lower $\mathrm{O}_{3}$ concentrations with greater and higher mixing in the UT, is in agreement with the patterns of change in the sub-tropics displayed in Fig. 7a. In the mid-latitudes, Olivié et al. (2004) find larger $\mathrm{O}_{3}$ concentrations in the MT with larger/higher convection in the simulations that use the fluxes from the ERA-40 reanalyses. These arise from enhanced downward transport in the higher latitudes. However, despite greater and higher convection in the mid-latitudes in STOCHEM-HadAM3 relative to MATCH-MPIC (Figs. 1b, h), MT increases are smaller. Therefore, we suspect differences other than those arising from the convection schemes also contribute to the contrasting effects of convective mixing displayed by the STOCHEM and MATCH-MPIC models. Interestingly, the relative effects of convection on $\mathrm{O}_{3}$ budget fluxes are larger in the MATCH model compared to STOCHEM, despite the generally smaller convective mass fluxes; this may be related to the longer tropospheric $\mathrm{O}_{3}$ lifetime in MATCH-MPIC (Table 1).

Differences in chemistry potentially arise from differences in both emission source strengths and chemical schemes.
A comparison of the emissions used in the two studies shows that NO surface, aircraft and ship emissions are similar but lightning $\mathrm{NO}_{\mathrm{x}}$ emissions are higher at $7 \mathrm{Tg} N / \mathrm{yr}$ in our study compared to $2 \mathrm{Tg} \mathrm{N} / \mathrm{yr}$ in Lawrence et al. (2003) (M. Lawrence, personal communication); anthropogenic NMHC emissions are also higher by $5-20 \mathrm{Tg} / \mathrm{yr}$ in STOCHEM, and isoprene is higher by $\sim 225 \mathrm{Tg} / \mathrm{yr}(\sim 65 \%)$ compared to MATCH (von Kuhlmann et al., 2003). The higher isoprene and lightning $\mathrm{NO}_{\mathrm{x}}$ emissions in our study may result in greater amounts of PAN formation and consequently a larger $\mathrm{UT} \mathrm{NO}_{\mathrm{x}}$ reduction, although higher isoprene also suggests higher $\mathrm{UT} \mathrm{HO}_{\mathrm{x}}$. Emissions of both lightning $\mathrm{NO}_{\mathrm{x}}$ and isoprene from vegetation carry high levels of uncertainty, and it is unclear whether the higher or lower levels of emissions more closely resemble the real world. Both these natural sources are sensitive to climate, and thus likely to respond to changes in climate (Stevenson et al., 2005a).

In addition, there may be significant model differences in chemical schemes in the two studies, particularly in the isoprene degradation schemes. The isoprene-lightning $\mathrm{NO}_{\mathrm{x}}$ interaction may be much less important in the MATCH model, resulting in larger increases in $\mathrm{O}_{3}$ production with convection. In STOCHEM, this mechanism limits the effectiveness of convection in promoting chemical production of UT $\mathrm{O}_{3}$, and consequently the impact of vertical $\mathrm{O}_{3}$ mixing is the process of overriding importance. Figure 2 shows simulated tropical PAN to be in agreement with observations to within \pm 1 standard deviation. There is some overestimation of PAN in parts of the UT, but also some overestimation of UT $\mathrm{NO}_{\mathrm{x}}$ (Sect. 3.1). Therefore, promotion of the conversion of $\mathrm{NO}_{\mathrm{x}}$ into PAN by convection seems a plausible process, since it acts to bring simulated $\mathrm{NO}_{\mathrm{x}}$ concentrations into better agreement with observations. However, other mechanisms such as excessive lightning $\mathrm{NO}_{\mathrm{x}}$ emissions or errors in their vertical distribution could also explain the $\mathrm{UT} \mathrm{NO}_{\mathrm{x}}$ overestimates in the tropics. In a model sensitivity study, von Kuhlmann et al. (2004) found that both isoprene and lightning emissions magnitudes, and isoprene degradation schemes, all had important influences on tropical $\mathrm{O}_{3}$. Further model sensitivity studies are needed to clarify how different emissions and isoprene schemes influence tropospheric $\mathrm{O}_{3}$ response to convective mixing.

Finally, vertical resolution and upper boundary conditions for $\mathrm{O}_{3}$, as discussed by Lawrence et al. (2003) could be another source of different responses with convective mixing. However, although the vertical grid resolution is lower in STOCHEM than in the MATCH-MPIC model used in the Lawrence et al. (2003) study the Lagrangian sampling in STOCHEM is at roughly the same resolution (50000 air parcels compared to $64 \times 32 \times(\sim 20$ tropospheric vertical levels)= approximately 41000 grid cells in the troposphere). 


\section{Conclusions}

Model experiments have been performed to examine the role of deep convective mixing in determining the distributions of tropospheric $\mathrm{O}_{3}$ and its precursors. In contrast to results from an earlier study with a model of similar chemical complexity (Lawrence et al., 2003), convective mixing in our study reduces the $\mathrm{O}_{3}$ burden, due to vertical $\mathrm{O}_{3}$ redistribution and associated lifetime changes. Convection of $\mathrm{O}_{3}$ precursors has several competing effects on $\mathrm{O}_{3}$ chemical production. Over tropical land, convection lofts surface sources of $\mathrm{NO}_{\mathrm{x}}$ and NMHCs in particular isoprene, tending to increase their concentrations in the MT and UT at the expense of the LT. However, in our model the subsidence associated with convection mixes downwards UT lightning $\mathrm{NO}_{\mathrm{x}}$. UT $\mathrm{NO}_{\mathrm{x}}$ is also converted to PAN by the introduction of peroxy acetyl radicals, an oxidation product of isoprene. The overall effect is a reduction in $\mathrm{UT} \mathrm{NO}_{\mathrm{x}}$, together with an increase in $\mathrm{UT} \mathrm{HO}_{\mathrm{x}}$; the net effect is a small increase in $\mathrm{O}_{3}$ production. However, this increase in $\mathrm{O}_{3}$ production is more than counteracted by the effects of convective mixing of $\mathrm{O}_{3}$ itself, and $\mathrm{UT} \mathrm{O}_{3}$ reduces. The features generated over the tropical land are assumed to be advected over the tropical oceans, although over the remote oceans, the impact of local vertical mixing becomes more dominant. Mid-latitudinal convection also reduces UT $\mathrm{O}_{3}$ resulting in a $13 \%$ decrease in the global $\mathrm{O}_{3}$ burden despite a $4 \%$ increase in chemical production. This apparent contradiction arises because the mean tropospheric $\mathrm{O}_{3}$ lifetime reduces substantially (by 16\%); this is mainly because less $\mathrm{O}_{3}$ resides in the UT, where its lifetime is longest. Comparison of convective mass fluxes from this study and that of Lawrence et al. (2003) reveal substantial differences in the strength and height of deep convection. We suspect that differences in isoprene chemistry schemes as well as lightning $\mathrm{NO}_{\mathrm{x}}$ and isoprene emissions magnitudes are also important. With such divergent results from two apparently similar models (in terms of resolution and complexity), and the importance of deep convective mixing processes in altering the state of the atmosphere on interannual and longer timescales, further studies with other models are needed to constrain this range of uncertainty.

Acknowledgements. This work was supported by the NERC UTLS thematic programme (NER/T/S/2000/01041). D. S. Stevenson was supported by NERC/Environment Agency fellowship funding (P4-F02, NER/J/S/2000/00840). The UGAMP project is thanked for computing resources to run the coupled HadAM3-STOCHEM model. Many thanks to P. van Velthoven for providing ERA-40 convective mass fluxes. Many thanks to M. Lawrence for providing convective mass fluxes used in MATCH-MPIC and also for his detailed review. Thanks also to 3 further anonymous reviewers. Thanks to J. Pyle and G. Zeng for useful discussions.

Edited by: A. Stohl

\section{References}

Beekmann, M., Kowol-Santen, J., Honore, C., Dugault, E., and Ancellet, G.: Modelling studies of boundary-layer to free troposphere exchange, in: Tropospheric Ozone Research, TOR-2 Eurotrac-2 Subproject Final Report, 37-41, 2003.

Chatfield, R. B. and Brost, R. A.: A two-stream model of the vertical transport of trace species in the convective boundary layer, J. Geophys. Res., 92, 13 263-13 276, 1987.

Christian H. J., Blakeslee, R. J., Boccippio, D. J., et al.: Global frequency and distribution of lightning as observed from space by the Optical Transient Detector, J. Geophys. Res., 108(D1), 4005, doi:10.1029/2002JD002347, 2003.

Collins, W. J., Stevenson, D. S., Johnson, C. G., and Derwent, R. G.: Tropospheric ozone in a global-scale three-dimensional Lagrangian model and its response to $\mathrm{NO}_{\mathrm{x}}$ emission controls, $\mathrm{J}$. Atmos. Chem., 26, 223-274, 1997.

Collins, W. J., Stevenson, D. S., Johnson, C. E., and Derwent, R. G.: Role of convection in determining the budget of odd hydrogen in the upper troposphere, J. Geophys. Res., 104(D21), 26927 26 942, doi:10.1029/1999JD900143, 1999.

Collins, W. J., Derwent, R. G., Johnson, C. E., and Stevenson, D. S.: A comparison of two schemes for the convective transport of chemical species in a Lagrangian global chemistry model, Q. J. R. Meteorol. Soc., 128, 991-1009, 2002.

Cubasch, U., Meehl, G. A., Boer, G. J., Stouffer, R. J., Dix, M., Noda, A., Senior, C. A., Raper, S., and Yap, K. S.: Projections of future climate change, in: Climate Change 2001: The Scientific Basis, Contribution of WG1 to the Third Assessment report of the IPCC, edited by: Houghton, J. T., Ding, Y., Griggs, D. J., et al., Cambridge University Press, England, 2001.

Dentener, F. D., Stevenson, D. S., Cofala, J., Mechler, R., Amann, M., Bergamaschi, P., Raes, F., and Derwent, R. G.: The impact of air pollutant and methane emission controls on tropospheric ozone and radiative forcing: CTM calculations for the period 1990-2030, Atmos. Chem. Phys., 5, 1731-1755, 2005,

SRef-ID: 1680-7324/acp/2005-5-1731.

Dickerson, R. R., Huffman, G. J., Luke, W. T., Nunnermacker, L. J., Pickering, K. E., Leslie, A. C. D., Lindsey, C. G., Slinn, W. G. N., Kelly, T. J., Daum, P. H., Delany, A. C., Greenberg, J. P., Zimmermann, P. R., Boatman, J. F., Ray, J. D., and Stedman, D. H.: Thunderstorms - an important mechanism in the transport of air pollutants, Science, 235(47897), 460-464, 1987.

Emmons, L. K., Hauglustaine, D. A., Muller, J.-F., Carroll, M. A., Brasseur, G. P., Brunner, D., Staehelin, J., Thouret, V., and Marenco, A.: Data composites of airborne observations of tropospheric ozone and its precursors, J. Geophys. Res., 105, $20497-$ 20 538, 2000.

Gauss, M., Myhre, G., Pitari, G., et al.: Radiative forcing in the 21 st century due to ozone changes in the troposphere and the lower stratosphere, J. Geophys. Res., 108(D9), 4292, doi:10.1029/2002JD002624, 2003.

Gregory, D., Kershaw, R., and Innes, P. M.: Parametrization of momentum transport by convection. II: Tests in single-column and general circulation models, Q. J. R. Meteorol. Soc., 123, 11531183, 1997.

Guenther, A., Hewitt, C. N., Erickson, D., Fall, R., Geron, C., Graedel, T., Harley, P., Klinger, L., Lerdau, M., McKay, W. A., Pierce, T., Scholes, B., Steinbrecher, R., Tallamraju, R., Taylor, J., and Zimmerman, P.: A global model of natural organic com- 
pound emissions, J. Geophys. Res., 100, 8873-8892, 1995.

Labrador, L. J., von Kuhlmann, R., and Lawrence, M. G.: The effects of lightning-produced $\mathrm{NO}_{\mathrm{x}}$ and its vertical distribution on atmospheric chemistry: sensitivity simulations with MATCHMPIC, Atmos. Chem. Phys., 5, 1815-1834, 2005,

\section{SRef-ID: 1680-7324/acp/2005-5-1815.}

Lawrence, M. G., von Kuhlmann, R., and Salzmann, M.: The balance of effects of deep convective mixing on tropospheric ozone, Geophys. Res. Lett., 30, 18, doi:10.1029/2003GL017644, 2003.

Lawrence, M. G. and Rasch, P. J.: Tracer Transport in Deep Convective Updrafts: Plume Ensemble versus Bulk Formulations, J. Atmos. Sci., 62, 2880-2894, 2005.

Lelieveld, J. and Crutzen, P. J.: Role of deep cloud convection in the ozone budget of the troposphere, Science, 264, 1759-1761, 1994.

Li, D. and Shine, K. P.: A 4-dimensional ozone climatology for UGAMP models, UGAMP internal report, University of Reading, UK, 1995.

Murphy, D. M. and Fahey, D. W.: An estimate of the flux of stratospheric reactive nitrogen and ozone into the troposphere, J. Geophys. Res., 99, 5325-5332, 1994.

Nakićenović, N., Alcamo, J., Davis, G., et al.: IPCC Special Report on Emissions Scenarios, Cambridge University Press, Cambridge, United Kingdom and New York, NY, USA, 599 pp., 2000 .

Olivié, D. J. L, van Velthoven, P. F. J., Beljaars, A. C. M., and Kelder, H. M.: Comparison between archived and off-line disgnosed convective mass fluxes in the chemistry transport model TM3, J. Geophys. Res., 109, D11303, doi:10.1029/2003/JD004036, 2004.

Pickering, K. E., Thompson, A. M., Dickerson, R. R., Luke, W. T., McNamara, D. P., Greenberg, J. P., and Zimmerman, P. R.: Model Calculations of Tropospheric Ozone Production Potential Following Observed Convective Events, J. Geophys. Res., 95, 14 049-14 062, 1990.

Pickering, K. E., Thompson, A. M., Tao, W.-K., Rood, R. B., McNamara, D. P., and Molod, A. M.: Vertical transport by convective clouds: Comparisons of three modeling approaches, Geophys. Res. Lett., 22, 1089-1092, 1995.

Pickering, K. E., Wang, Y., Tao, W.-K., Price, C., and Muller, J.F.: Vertical distributions of lightning $\mathrm{NO}_{\mathrm{x}}$ for use in regional and global chemical transport models, J. Geophys. Res., 103(D23), 31 203-31 216, 1998.

Pope, V. D., Gallani, M. L., Rowntree, P. R., and Stratton, R. A.: The impact of new physical parametrizations in the Hadley Centre climate model: HadAM3, Clim. Dyn., 16, 123-146, 2000.

Prather, M., Ehhalt, D., Dentener, F., et al.: Atmospheric Chemistry and Greenhouse Gases, in: Climate Change 2001: The Scientific Basis, Contribution of WG1 to the Third Assessment report of the IPCC, edited by: Houghton, J. T., Ding, Y., Griggs, D. J., et al., Cambridge University Press, England, 2001.
Prather, M. J. and Jacob, D.: A persistent imbalance in $\mathrm{HO}_{\mathrm{x}}$ and $\mathrm{NO}_{\mathrm{x}}$ photochemistry of the upper troposphere driven by deep tropical convection, Geophys. Res. Lett., 24, 3189-3192, 1997.

Price, C., Penner, J., and Prather, M.: $\mathrm{NO}_{\mathrm{x}}$ from lightning 1. Global distribution based on lightning physics, J. Geophys. Res., 102, 5929-5941, 1997.

Rasch, P. J., Mahowald, N. M., and Eaton, B. E.: Representations of transport, convection, and the hydrologic cycle in chemical transport models: Implications for the modeling of short-lived and soluble species, J. Geophys. Res., 102(D23), 28 127-28 138, doi:10.1029/97JD02087, 1997.

Sanderson, M. G., Collins, W. J., Derwent, R. G., and Johnson, C. E.: Simulation of global hydrogen levels using a Lagrangian three-dimensional model, J. Atmos. Chem., 46, 15-28, $2003 \mathrm{a}$.

Sanderson, M. G., Jones, C. D., Collins, W. J., Johnson, C. E., and Derwent, R. G.: Effect of climate change on isoprene emissions and surface ozone levels, Geophys. Res. Lett., 30(18), 1936, doi:10.1029/2003GL017642, 2003 b.

Seinfeld, J. H. and Pandis, S. N.: Atmospheric Chemistry and Physics: From air pollution to climate change, John Wiley \& Sons, New York, pp. 1326, 1997.

Stevenson D. S., Doherty, R. M., Sanderson, M. G., Collins, W. J., Johnson, C. E., and Derwent, R. G., Radiative forcing from aircraft $\mathrm{NO}_{\mathrm{x}}$ emissions: Mechanisms and seasonal dependence, J. Geophys. Res., 109, D17307, doi:10.1029/2004JD004759, 2004.

Stevenson D. S., Doherty, R. M., Sanderson, M. G., Collins, W. J., Johnson, C. E., and Derwent, R. G.: Impacts of climate change and variability on tropospheric ozone and its precursors, Faraday Discuss., 130, doi:10.1039/b417412g, 2005a.

Stevenson, D. S., Dentener, F. D., Schultz, M. G., et al.: Multimodel ensemble simulations of present-day and near-future tropospheric ozone, J. Geophys. Res., in press, 2005b.

Tiedtke, M.: A comprehensive mass flux scheme for cumulus convection in large-scale models, Mon. Weather. Rev., 117, 1779$1800,1989$.

von Kuhlmann, R., Lawrence, M. G., Crutzen, P. J., and Rasch, P. J.: A model for studies of tropospheric ozone and non-methane hydrocarbons: Model description and ozone results, J. Geophys. Res., 108(D9), 4294, doi:10.1029/2002JD002893, 2003.

von Kuhlmann, R., Lawrence, M. G., Pöschl, U., and Crutzen, P. J.: Sensitivities in global scale modeling of isoprene, Atmos. Chem. Phys., 4, 1-17, 2004,

SRef-ID: 1680-7324/acp/2004-4-1.

Ziemke J. R. and Chandra, S.: La Nina and El Nino induced variabilities of ozone in the tropical lower atmosphere during 1970-2001, Geophys. Res. Lett., 30(3), 1142, doi:10.1029/2002GL016387, 2003. 